\title{
12. THE MAGNETOSTRATIGRAPHY OF LEG 94 SEDIMENTS 1
}

\author{
Bradford M. Clement and Frank Robinson, Lamont-Doherty Geological Observatory and Department of \\ Geological Sciences, Columbia University²
}

\begin{abstract}
The primary objective of DSDP Leg 94 was to obtain continuous paleoclimatic records along a roughly north-south transect in the North Atlantic. The magnetostratigraphy of 21 holes at 6 sites cored with the hydraulic piston corer and extended-core-barrel corer is presented here and establishes an independent chronology for these sediments. Nearly complete records were obtained for the last $2.5 \mathrm{~m}$.y.; in addition, deeper drilling at three sites to satisfy tectonic and paleoceanographic objectives produced older sections suitable for magnetostratigraphic study, allowing first-order correlations of the polarity sequences with calcareous and siliceous microfossil events.

The sections with high sediment accumulation rates yielded very detailed records of polarity history and allowed three short normal-polarity zones within the Matuyama Chronozone to be detected, in addition to the Jaramillo and Olduvai subchronozones. A short reversed-polarity zone also occurs, within the upper intervals of the Gauss Chronozone. These short zones are present in multiple holes, ruling out the possibility that they might be of local origin. Correlation of these short zones with radiometrically dated polarity zones in igneous rocks strongly supports the interpretation of these polarity zones as records of true geomagnetic polarity chrons.
\end{abstract}

\section{INTRODUCTION}

The hydraulic piston corer (HPC) was used on DSDP Leg 94 to recover long undisturbed sections of deep-sea sediment at six sites in the North Atlantic; these sections are ideally suited for magnetostratigraphic study. At depths below HPC refusal, the extended-core-barrel (XCB) corer recovered cores relatively undisturbed compared with rotary-drilled cores, and these proved suitable for paleomagnetic study. The magnetostratigraphic results for these sites are presented here; they provide a time framework with which biostratigraphic, paleoclimatic, tectonic, and other studies of these sediments may be integrated and together correlated with the geomagnetic polarity time scale.

The primary objective of Leg 94 was to obtain a continuous high-resolution paleoclimatic record along a transect from $35^{\circ} \mathrm{N}$ to $55^{\circ} \mathrm{N}$ in the North Atlantic. By coring multiple HPC holes at each site and offsetting core depths in adjacent holes, the intervals lost between cores or in disturbed intervals were recovered from adjacent holes. Determination of the magnetostratigraphy while on site yielded tie-lines between holes which, used together with lithologic correlations (see Ruddiman et al., this volume), allowed a check on the relative depth-offset between holes. The depth-offset could then be adjusted so that almost $100 \%$ recovery was achieved in the composite sections, resulting in nearly continuous records of sedimentation for the last 2.5 m.y.

\footnotetext{
${ }^{1}$ Ruddiman, W. F., Kidd, R. B., Thomas, E., et al., Init. Repts, DSDP, 94: Washington (U.S., Govt. Printing Office).

2 Addresses: (Clement, present address) Ocean Drilling Program, Texas A\&M University, College Station, TX 77843; (Robinson) Lamont-Doherty Geological Observatory and Department of Geological Sciences, Columbia University, Palisades, NY 10964.
}

\section{METHODS}

Paleomagnetic samples were taken from the split core sections by pressing $7-\mathrm{cm}^{3}$ plastic cubes into the sediment. At depths below which the sediment became too stiff to use the plastic boxes, oriented sections were removed and samples were cored from these sections using a drill press and a diamond drill bit. Use of the Custer orientation device proved unsuccessful, so relative orientation between cores was not available. Within-core orientation was maintained by orienting the samples with respect to the split face of the core and the vertical. Sediment accumulation rates encountered at the Leg 94 sites averaged between 30 and $50 \mathrm{~m} / \mathrm{m}$.y. These rates allowed a detailed polarity stratigraphy to be identified, using a sampling interval of one sample per core section $(1.5 \mathrm{~m})$. Two samples per section were taken when required by low accumulation rates or in intervals of frequent reversals (e.g., the Miocene at Site 608)

The shipboard Digico magnetometer was not used during this cruise, because of the high noise level of the instrument, which made it difficult to measure specimens with magnetization intensities of less than 2 $\times 10^{-5} \mathrm{~A} / \mathrm{m}$. A portable fluxgate spinner magnetometer was taken on board and used instead for all the shipboard measurements. The direction and magnitude of the natural remanent magnetization (NRM) of the samples were measured using this magnetometer. Samples representative of different lithologies and distinct intervals of the cores were subjected to progressive partial alternating-field (AF) demagnetization. The remaining samples were demagnetized at the appropriate peak field level on the basis of results of the progressive AF demagnetization studies.

Samples from intervals characterized by poor shipboard polarity records were remeasured using a cryogenic magnetometer in the Lamont-Doherty paleomagnetics lab. Additional shore-based sampling was done to define further the polarity records in sections (such as the lower Miocene in Hole 608) requiring more closely spaced sampling.

\section{Electro-Osmotic Knife Tests}

The electro-osmotic knife was developed for cutting through sediment without distorting sediment structures (for a full discussion of the use of the knife see Weaver and Schultheiss, 1983; Sturm and Malter, 1972; and McMillen et al., 1977). In operation the cutting blade of the knife serves as one of two electrodes through which a direct current is applied to the sediment. In deep-sea sediments containing salt water (which serves as an electrolyte), gas accumulates along the cutting edge of the knife, allowing it to slice through the sediment with very little deformation of the cut surface. It was originally hoped that 
this tool could be used to split the Leg 94 cores and thereby reduce the smearing of the split face caused by the standard method of splitting the cores with a wire. Before this instrument was used, a series of tests was run to determine the nature and extent of the possible effects its use might have on the remanent magnetization of these sediments.

Four samples, chosen on the basis of lithology (two marls and two oozes), were taken from a core using $7-\mathrm{cm}^{3}$ plastic boxes. The NRM of the samples was measured using a portable fluxgate magnetometer. Progressive AF demagnetization studies on other samples from these intervals indicate that unstable or secondary components are readily removed by treatment at $10 \mathrm{mT}$. On the basis of these results, the samples used in this study were partially demagnetized using a $10-\mathrm{mT}$ peak field before being subjected to testing with the electro-osmotic knife.

Two types of test were run with the knife. In the first the voltage supplied by the dc power supply was progressively increased, whereas in the second the voltage was held constant while the amperage was allowed to increase. In each case the sample was oriented with respect to the ambient field so that in the sample's coordinate system the field vector had a mean declination of $179^{\circ}$, an inclination of $-42^{\circ}$, and a magnitude of $0.0377 \mathrm{mT}$. The electrodes were placed at the top of the sediment at either edge of the plastic box, causing the current to flow in a positive $Y$ direction.

In the first set of tests, using three samples (two marls and one ooze), power was supplied to the electrodes for a minimum of $15 \mathrm{~s}$, starting at $8.5 \mathrm{~V}$ and increasing up to $49 \mathrm{~V}$. After each application of power the samples were measured using the spinner magnetometer. In Figure 1 the directions measured after each power application are shown plotted on equal-area stereographic projections. None of the samples exhibited a significant change of direction within this range of voltages. The remanent magnetizations of the two marls had NRM declinations which differed by nearly $90^{\circ}$. Neither showed significant changes, suggesting that use of the knife was not causing magnetization in either the ambient field direction or a direction related to current flow.

The normalized intensities after each power application are shown in Figure 2A. This plot illustrates that, throughout the range of voltages used, the intensities of magnetization did not vary significantly. Only in the case of the ooze does the intensity appear to decrease after the first treatment at $8.5 \mathrm{~V}$. The directional and intensity behavior at higher treatments suggests, however, that this may just be a result of the sample's weak NRM magnetization relative to that of the marls.

After being treated with the maximum voltage, $49 \mathrm{~V}$, one of the marl samples and the ooze sample were progressively demagnetized using a single-axis AF demagnetizer. In Figure 2B the normalized intensities are shown plotted against peak alternating field. Results from the progressive demagnetization of a sample not treated with the knife are shown for comparison (Sample 609-1-4, $110 \mathrm{~cm}$ ). Use of the knife does not appear to affect the coercivity spectra of these sediments or the effectiveness of the demagnetization process.

One ooze sample was tested by holding the voltage constant at $30 \mathrm{~V}$ while allowing the amperage to increase. The normalized intensities after each treatment are plotted in Figure 2C. At these low amperages no significant variation was observed in the magnetizations.

In practice, the current that can be caused to flow through a sample is a function of the sample's water content. The tests conducted here should be extended to higher voltages, using samples with variations in water content, to test adequately the effect of stronger currents produced by the knife. The results reported here, however, suggest that at low voltages use of the knife has no significant effects on the remanent magnetizations of these sediments. This tool may therefore be used without affecting the magnetic properties of these sediments.

\section{MAGNETIC POLARITY TIME SCALE}

The polarity records obtained from Leg 94 sediments are correlated with the magnetic polarity time scale (MPTS) of Berggren, Kent, and Van Couvering (in press). In recent years the MPTS has been revised several times; the reader is referred to Berggren, Kent, and Van Couvering (in press) for a discussion of these revisions and their relative merits. Extension of the previously existing magnetostratigraphic nomenclature (developed for Neogene sequences) to older sections has resulted in confu-
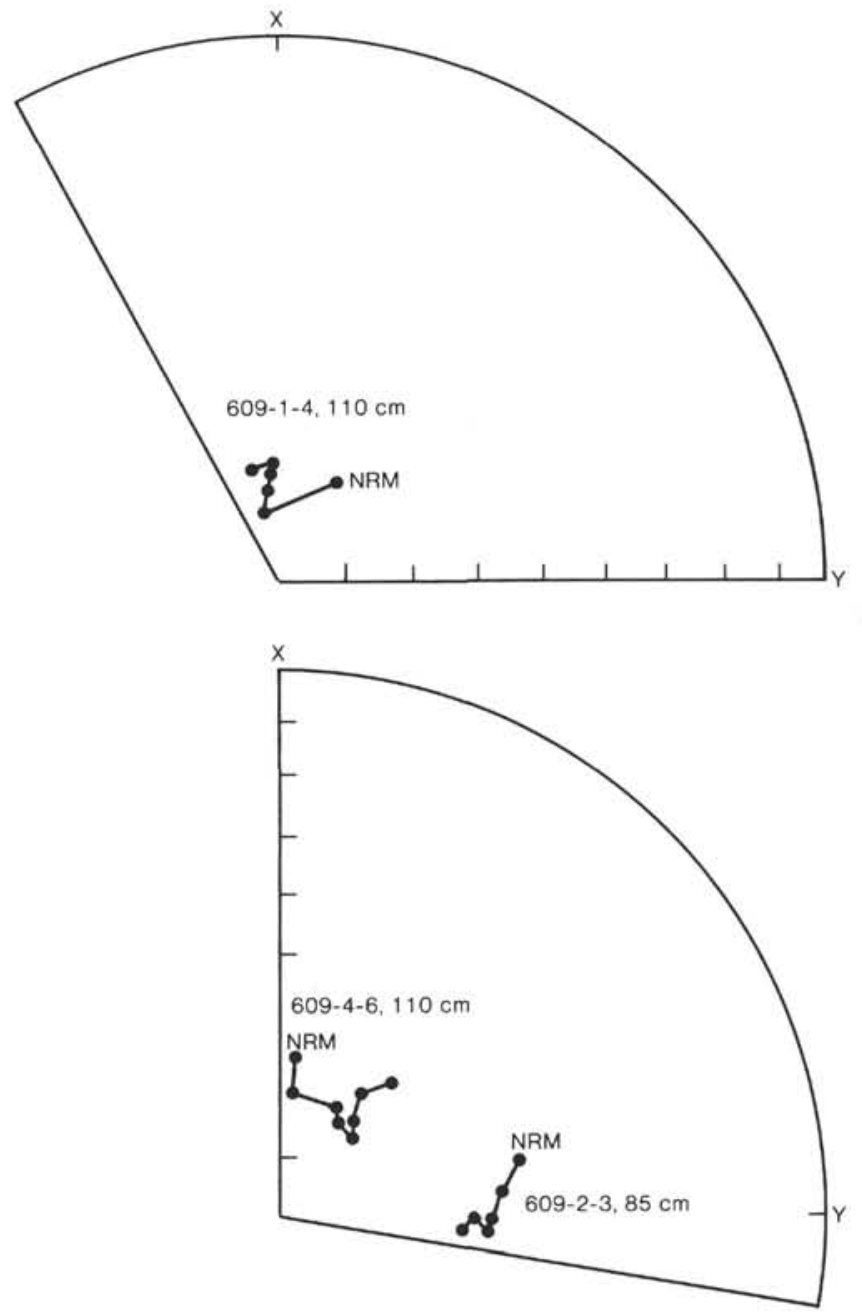

Figure 1. Magnetization directions measured after treatment at progressively higher voltages using the osmotic knife, plotted on equalarea projections.

sion because the numbering system of chrons (previously referred to as epochs; see Hedberg et al., 1979) becomes confusing when one attempts to correlate polarity zones with the numbered marine anomaly sequence (Alvarez et al., 1977; Butler and Coney, 1981). La Brecque et al. (1983) suggested a nomenclature which reduces this confusion. They defined pre-Neogene chrons by incorporating the numbering system of the marine magnetic anomalies as defined by Heirtzler et al. (1968). Berggren, Kent, and Van Couvering (in press) extended this system by adapting the nomenclatural system of Cox (1982) for labeling the normal and reversed intervals that fall between the numbered anomalies. For example, in this system the polarity sequence that falls between Anomalies $6 \mathrm{~A}$ and $6 \mathrm{~B}$ is called Chron $\mathrm{C} 6 \mathrm{AB}$.

The numbering system was further modified to correct for the erroneous correlation of Epoch 9 with Anomaly 5 time (Ryan et al., 1974; Theyer and Hammond, 1974). (Note that "epochs" were originally defined as polarity zones in the sediment, not as time units; in the current nomenclature they would be referred to as chronozones.) Recent findings indicated that Epoch 11 should 

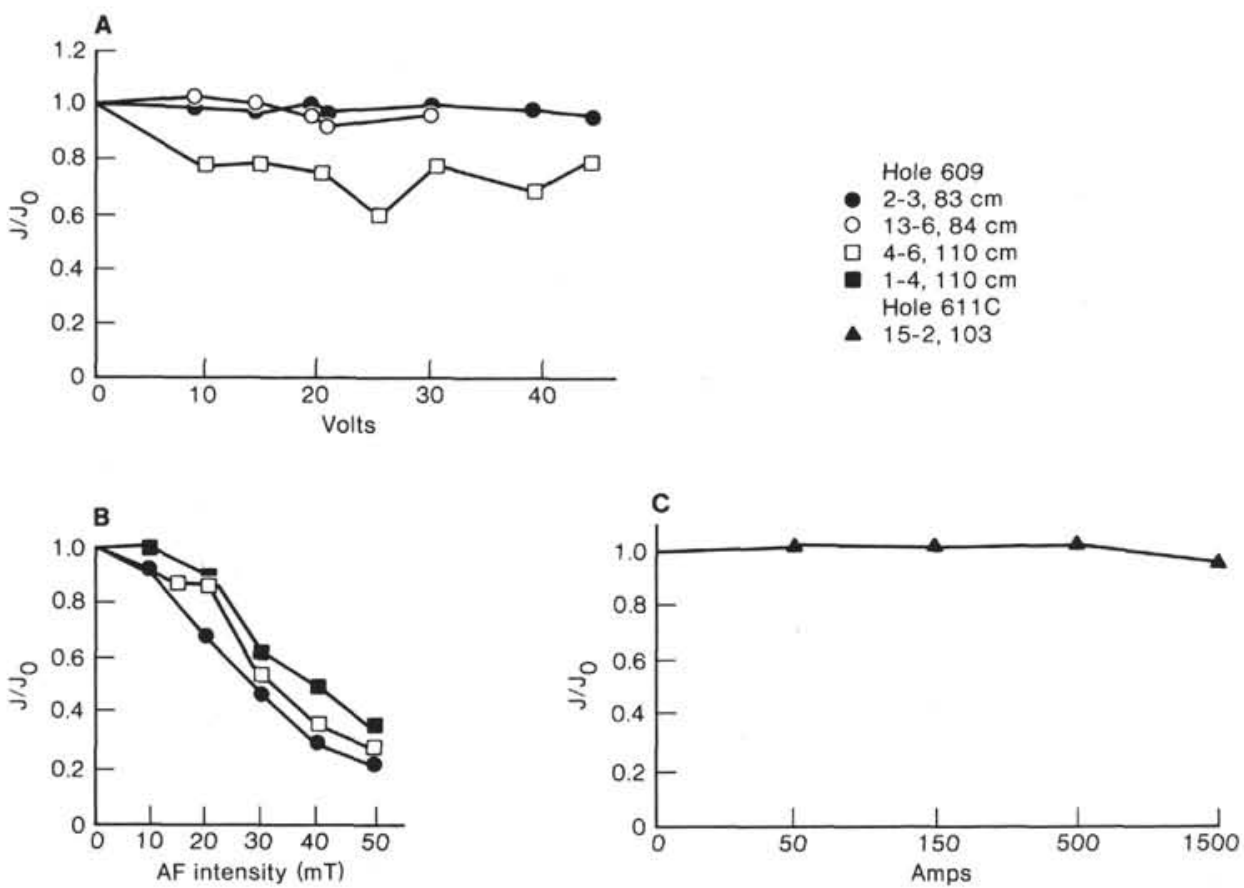

Figure 2. Normalized magnetization intensities after treatment with the osmotic knife. A. Intensities after treatment at progressively higher voltages. B. Intensities during progressive AF demagnetization of two samples which had been treated at $49 \mathrm{~V}$ with the knife and, for comparison, one untreated sample $(609-1-4,110 \mathrm{~cm})$. C. Intensities after treatment at progressively higher amperages.

have been correlated with Anomaly 5 time (Miller et al., 1985; Khan et al., 1985; Hsü et al., 1984). This indicates that biostratigraphic markers correlated with Epoch 11 are younger than previously thought, since this epoch has been moved relative to the MPTS. Berggren, Kent, and Van Couvering (in press) redefined the boundaries of Epochs 7 through 11, calling them Chrons 7 through 11 , and renamed the older epochs using the chron terminology, as already described. This solution appears to clarify the problem while maintaining as much consistency as possible with the nomenclature embedded in the literature.

\section{RESULTS}

Examples of results of progressive AF demagnetization are shown plotted as vector endpoint diagrams in Figure 3. In general, samples from the various lithologies encountered at the six sites are characterized by stable, univectorial magnetizations. In each case, treatment at $10-\mathrm{mT}$ peak field was successful in removing low-coercivity components, leaving a more stable component identified by a linear trajectory which decays toward the origin with treatment at higher levels. The remaining samples from these intervals were demagnetized using a peak field of $10-\mathrm{mT}$.

Relative orientation between cores was not available on Leg 94, so the inclinations alone were used to determine the magnetic polarity records. The inclinations predicted by an axial dipole field ranged from $56^{\circ}$ at Site $606\left(37^{\circ} \mathrm{N}\right.$ Lat.) to $68^{\circ}$ at Site $610\left(53^{\circ} \mathrm{N}\right.$ Lat. $)$, and are steep enough to allow an unambiguous polarity determination, regardless of the lack of declination control. The inclination record for each site is plotted against sub-bottom depth in Figures 4-12. In these figures, the composite polarity log for each site is based on the inclination record; positive inclinations, interpreted as normal polarity, are shown in black, and negative inclinations, interpreted as reversed polarity, are indicated by white intervals on the polarity log bar diagrams. Polarity zones represented by only one sample were resampled when possible, unless the same polarity zone was observed in an adjacent hole. Otherwise, such polarity zones are considered tentative. At each hole, the shipboard biostratigraphic age determinations constrained the correlation of observed polarity records with the geomagnetic time scale. Correlation of the composite polarity logs with the MPTS (Berggren, Kent, and Van Couvering, in press) is indicated by lines drawn between the composite $\log$ and the MPTS at the major reversal boundaries. The depths and ages of the major reversal boundaries for each hole are also given in the Appendix, with the samples bounding the reversal and their depths indicated.

\section{Site 606}

The results for Site 606 are presented in Figure 4. At Hole 606,18 cores of undisturbed foraminiferal nannofossil ooze were recovered, down to a sub-bottom depth of $165.7 \mathrm{~m}$; the sediments are lower Pliocene to Holocene. Paleomagnetic samples were taken every $1.5 \mathrm{~m}$ (one per section). This sampling interval was halved to $0.75 \mathrm{~m}$ in Cores 606-3 through 606-9, in an effort to define adequately the polarity subchronozones within the Matuyama Chronozone. The inclinations observed after AF treatment at $10 \mathrm{mT}$ are plotted versus sub-bottom depth in Figure 4 . The polarity zones defined by the inclination record are indicated in the composite polarity log, and 

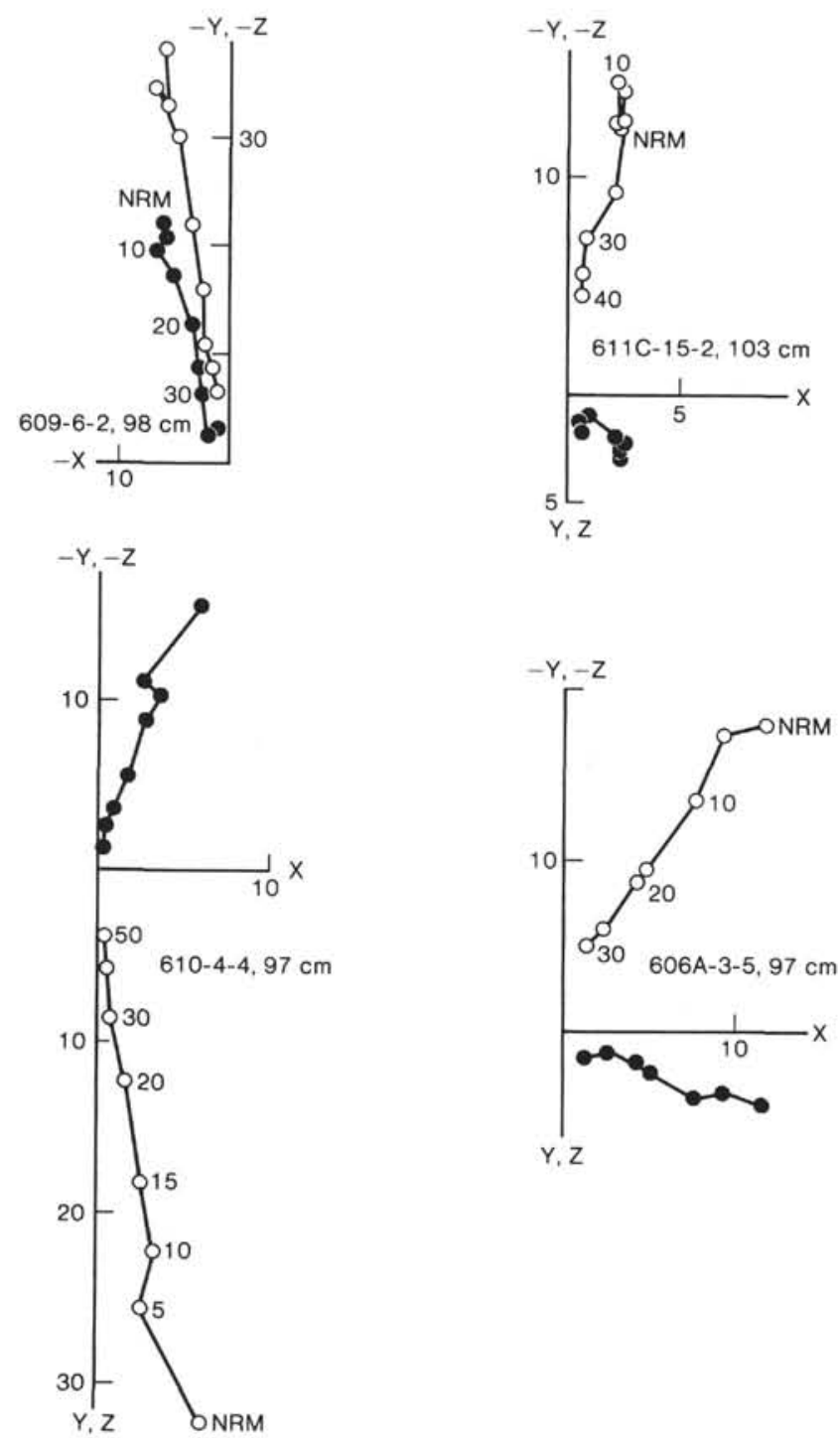

Figure 3. Results of progressive AF demagnetization plotted as vector endpoint diagrams (Zijderveld, 1967). Open symbols represent projections onto the vertical plane; solid symbols represent projections onto the horizontal plane. AF intensity in milliteslas; magnetization intensity in units of $10^{-3} \mathrm{~A} / \mathrm{m}$.

generally the correlation of these intervals with the MPTS is straightforward. Within the Matuyama Chronozone, four short normal-polarity zones are present, but only one, located in Core 606-7, is represented by more than one sample. The correlation of this subchronozone with the Olduvai Subchron is consistent with the shipboard biostratigraphers' placement of the Pliocene/Pleistocene boundary in Core 606-7 (Site 606 report, this volume). The other short subchronozones possibly represent the Jaramillo, Cobb Mountain, and Reunion subchrons, respectively, and will be discussed in detail later. The Gauss Chronozone and the upper portion of the Gilbert (to just below the Cochiti) were also identified.

The NRM intensities after treatment at $10 \mathrm{mT}$ decreased downcore from approximately $5 \times 10^{-2}$ to less than $1 \times 10^{-3} \mathrm{~A} / \mathrm{m}$ in Cores 606-8 through 606-13. These intensities then began to increase slightly in Cores 606-14 to $606-18$.
In Hole 606A, paleomagnetic samples were taken only across key intervals necessary to supplement the record obtained from Hole 606. Reversals correlated with the base of the Brunhes and Olduvai occur in Cores 606A-3 and 606A-7. These reversal boundaries helped monitor the amount of depth-offset between the two holes at Site 606. The standard sampling scheme of one sample per $1.5 \mathrm{~m}$ was resumed in Core 606A-16. Unfortunately, Core 606A-18 was deformed and was heated with a torch on deck to remove it from the drill pipe, so it was not sampled.

Correlation of the normal subchronozones in Cores 606A-17 and 606A-19 with the time scale is complicated by the gap in sampling from Core 606A-18, but they are tentatively correlated with the Cochiti and Nunivak subchrons of the Gilbert Chron.

\section{Site 607}

The inclination records obtained from Holes 607 and $607 \mathrm{~A}$ are shown in Figure 5. At Hole 607 a nearly continuous record was obtained down to $284.4 \mathrm{~m}$ sub-bottom depth; upper Miocene to Holocene sediment was recovered. Samples were taken (at 1.5 -m intervals) from the entire cored interval from Hole 607, Core 607-17, which was disturbed throughout because the core liner shattered during coring. The NRM intensities decreased downcore until, by Core 607-18, they approached the noise level of the magnetometer. Samples from Cores 607-18 through 607-30 were remeasured using a cryogenic magnetometer at the Lamont-Doherty lab. The intensities of samples from Cores 607-26 to 607-30 were below the practical noise level of the cryogenic magnetometer (samples with magnetization intensities less than $2 \times 10^{-5} \mathrm{~A} / \mathrm{m}$, for a $10-\mathrm{cm}^{3}$ specimen, could not be measured with acceptable internal consistency). These results are not interpretable and are not shown.

Samples were taken from Hole $607 \mathrm{~A}$ at $1.5-\mathrm{m}$ intervals only where necessary to define the major polarity zones identified in Hole 607.

The polarity log from both holes is readily correlated with the MPTS down to a depth of $140 \mathrm{~m}$, at which point coring disturbances complicate the record. At both Hole 607 and Hole 607A, a short reversed-polarity zone occurs a few meters below the top of the Gauss Chronozone. The base of the Gauss Chronozone is offset between the holes by nearly $6 \mathrm{~m}$. Again, because of coring disturbances, continuous sampling was not possible across this interval in either hole. These sampling gaps render the interpretation of these levels ambiguous.

The Gilbert Chronozone in Hole 607 contains 5 short normal-polarity subchronozones, the uppermost of which is represented by only one sample. This polarity zone was not observed in the correlative interval in Hole 607A, so identification of this zone is considered tenuous. The four remaining polarity zones are correlated with the four subchrons in the Gilbert Chron.

\section{Site 608}

Site 608 is on the flank of the King's Trough tectonic province; the objective of drilling there was to obtain a stratigraphic record of the area's tectonic history. For this reason, Hole 608 was continuously cored (HPC to 

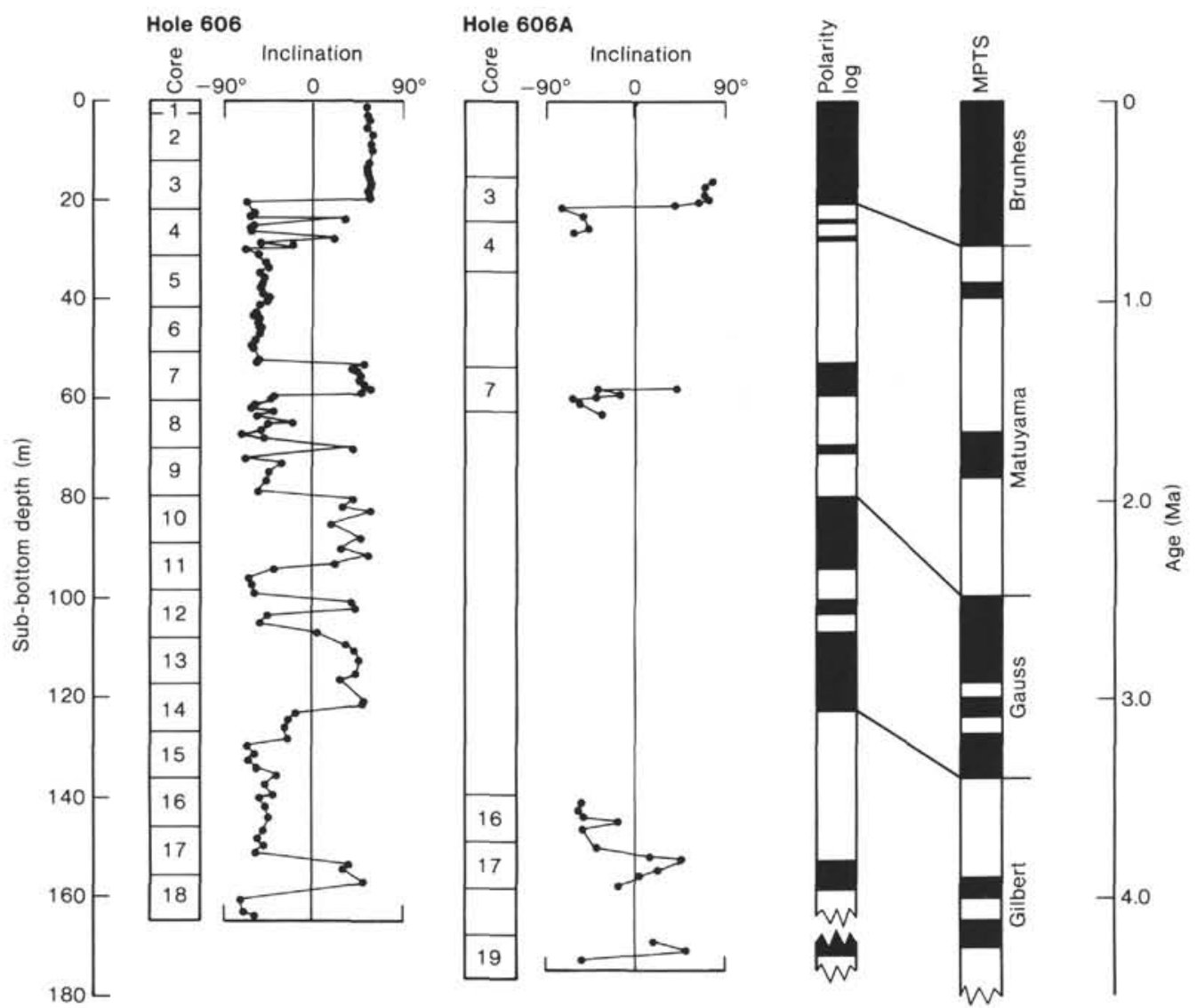

Figure 4. Results for Site 606 samples after treatment at 10-mT peak field, shown with inclinations plotted versus sub-bottom depth. The depths of the tops of the cores are indicated. The inclination records are summarized in a composite polarity $\log$ for Site 606 . The composite $\log$ is correlated with the magnetic polarity time scale (MPTS). The time scale is plotted relative to the ages shown at the right side of the figure. See Appendix for specific depths of reversals.

refusal and then $\mathrm{XCB}$ ) to basement at $530.3 \mathrm{~m}$. A nearly continuous sequence of upper Eocene to Quaternary sediments was recovered; an up to 9.5-m.y. hiatus separates middle upper Eocene from middle upper Oligocene. Hole $608 \mathrm{~A}$ was cored to fill coring gaps in the upper portion of Hole 608; it was HPC cored to $146.4 \mathrm{~m}$ and Pliocene through Holocene sediments were recovered.

A nearly continuous magnetostratigraphic record, from the Quaternary to the middle upper Oligocene, was obtained from Hole 608; below the middle upper Oligocene, gaps resulting from coring disturbances combined with the presence of a major hiatus, defined in both the lithology and biostratigraphy, to cause the record to be less complete through the Oligocene and into the Eocene.

The polarity record at Hole 608 is presented in Figure 6. Shore-based sampling of Cores 608-12 through 60854 resulted in an average sampling interval of $0.75 \mathrm{~m}$. All the samples from these cores were remeasured using the cryogenic magnetometer at the Lamont lab, and these results are included in Figure 6. Samples from Cores 608-14 through 608-16 exhibited magnetizations below the noise level of the cryogenic magnetometer, so the polarity zonation of this interval cannot be interpreted.

Cores 608-1 through 608-13, however, appear to contain a record of the Brunhes to late Gilbert polarity his- tory. Within the Matuyama Chronozone, four subchronozones are represented. The Jaramillo Subchronozone occurs in the top of Core 608-3, and is followed downcore by a single sample exhibiting steep positive inclinations in Core 608-3, Section 5. A normal-polarity zone characterized by very shallow, positive inclinations occurs in the base of Core 608-5 and the top section of Core 608-6. A subchronozone with more fully normal inclinations is present in the base of Core 608-6. This normal zone is correlated with the Olduvai Subchron on the basis of shipboard biostratigraphic data (Site 608 report, this volume).

Cores 608-17 through 608-46 represent a nearly continuous record of polarity history from the upper Miocene to the upper Oligocene. The NRM intensities increased through this interval to well above the shipboard magnetometer's noise level, and were readily measurable. In Cores 608-29 through 608-34, the sediment was frequently brecciated, and intervals suitable for sampling were often difficult to find. Consequently, the data from this section are generally of poorer quality than that from above and below. Cores 608-35 through 608-40 contained indurated sediment that was easy to sample properly. The inclination record through these cores is very good, but the average inclination values $\left(40^{\circ}\right)$ are well below the average values of 60 to $65^{\circ}$ observed in the 

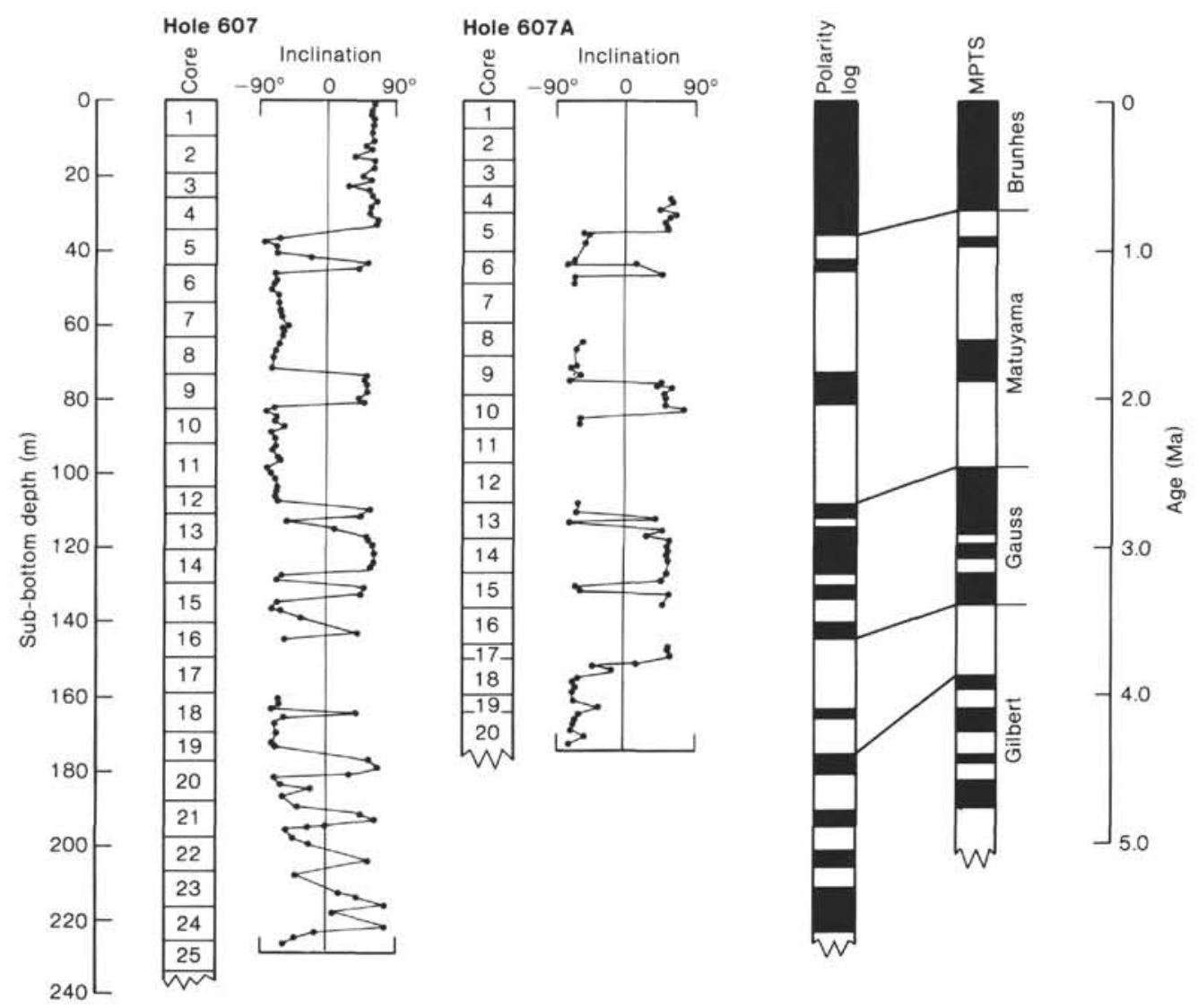

Figure 5. Results for Site 607 samples after treatment at $10 \mathrm{mT}$. See Figure 4 caption for further explanation.

upper parts of this hole. These shallow inclinations may be a product of compaction. This interpretation is supported by the presence of dissolution features (see barrel sheets) and faults, as evidenced by slickensides.

Below Core $608-46$, poor recovery becomes a more important complication, and the limited data obtained from Cores 608-52 through 608-54 do not yield a readily interpretable polarity history.

Correlation of the polarity log with the MPTS is shown in Figure 6. As already indicated, correlation of the polarity zones with the time scale is not complicated above Core $608-14$, and these correlations are supported by biostratigraphic data (Site 608 report, this volume). The same is true for Cores 608-18 through 608-27; the approximately $40-\mathrm{m}$-thick normal-polarity zone in Cores 608-23 to $608-27$ is correlated with Chron C5N.

The high frequency of polarity reversals in both the observed inclination record from Hole 608 and the correlative interval of the time scale (Blakely, 1974; Berggren, Kent, and Van Couvering, in press) cause the detailed correlation to be less certain for Cores 608-28 through 608-34. Sampling difficulties encountered in this interval further complicate the matter. The correlations with the time scale are supported, however, by biostratigraphic data (Site 608 report, this volume), which generally agree with the magnetobiostratigraphic records for Holes 563 and 558 (Miller et al., 1985; Khan et al., 1985).

The data from Cores 608-34 through 608-44 are of high quality; the inclinations form a square wave which is correlated with Chrons C5B through C6B. It appears that Chron C5D is not fully represented; this interval may be a compressed section. From this depth to the bottom of the hole, coring disturbances disrupt the record. The normal subchronozones recorded in Cores 608-45 and 608-46 are correlated with Chron C6C. Because Core 608-47 recovered no sediment, an alternative correlation of the normal subchronozones with Chron $\mathrm{C} 7$ is possible.

The record in Cores $608-48$ through $608-50$ is correlated with Chrons 8 and 9. Biostratigraphic evidence (Site 608 report, this volume) indicates the presence of an unconformity separating Sample 608-49-4, 38-40 cm (lower Oligocene) from Sample 608-50-1, 38-40 cm (upper Eocene), making correlation based on the reversal sequence alone very tenuous. More sampling gaps downcore make correlations of the polarity zones observed in Cores 608-52 and 608-54 difficult. There may be an unconformity near the top of Core 608-49; but reworking makes biostratigraphic assignments tenuous (Miller, personal communication, 1984), so the correlation of the reversed magnetozone in Core 608-49 is uncertain. The hole was cored over crust of Anomaly 18 age, however (Miles and Kidd; Kidd and Ramsay, this volume), and the bottom of the hole is therefore constrained to be correlative with Chron $\mathrm{C} 18$ or younger. On this basis, a possible correlation of these normal-polarity zones with Chrons $\mathrm{C} 16$ and $\mathrm{C} 17$ is indicated in Figure 6.

The results for Hole 608A are shown in Figure 7. Samples were taken from intervals required to define the ma- 


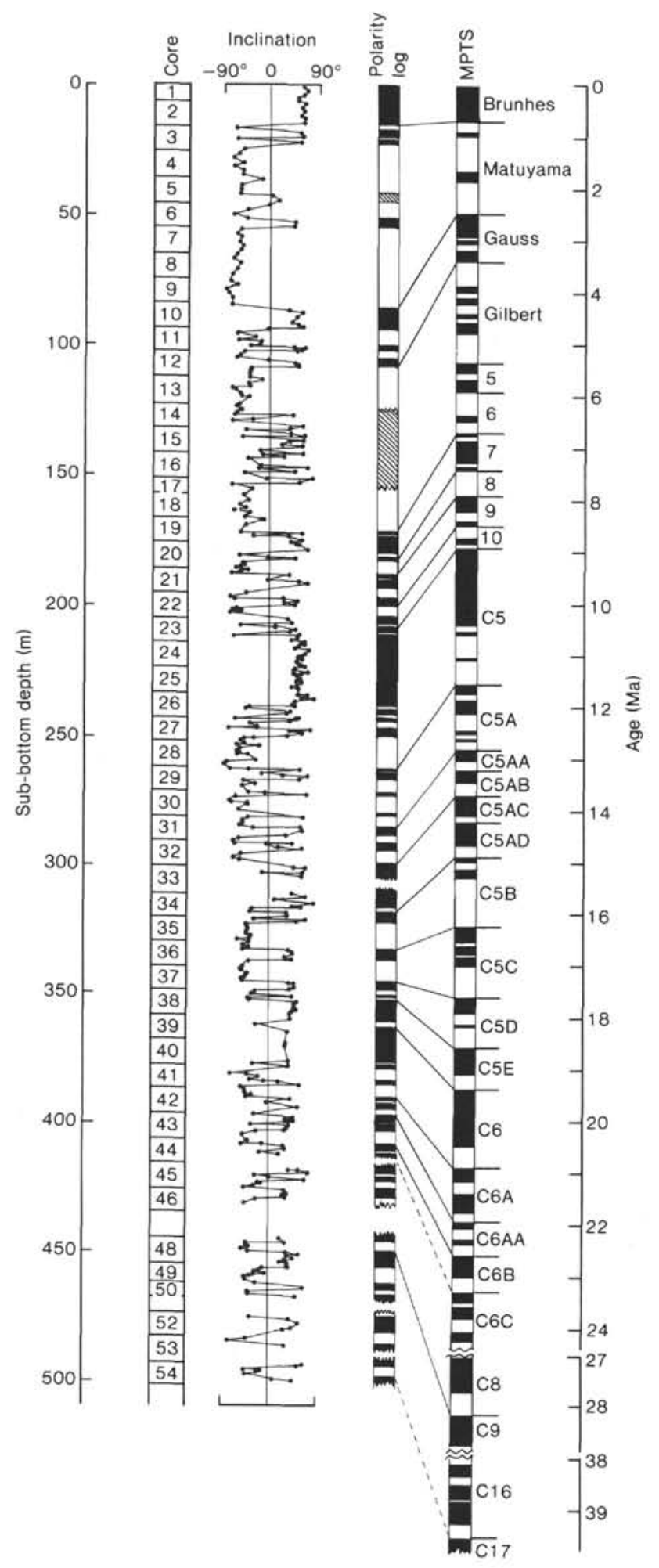

Figure 6. Results for Hole 608 samples after treatment at $10 \mathrm{mT}$. (Hachured areas indicate that data give no reliable information on polarity. Upper interval: slump [see Takayama and Sato, this volume]. Lower interval: low intensity.) See Figure 4 caption for further explanation.

jor polarity-zone boundaries (Brunhes/Matuyama, Olduvai). Continuous sampling was resumed in Core 608A-9 and continued through Core 608A-16. The quality of the data for Cores $608 \mathrm{~A}-13$ through $608 \mathrm{~A}-16$ is generally

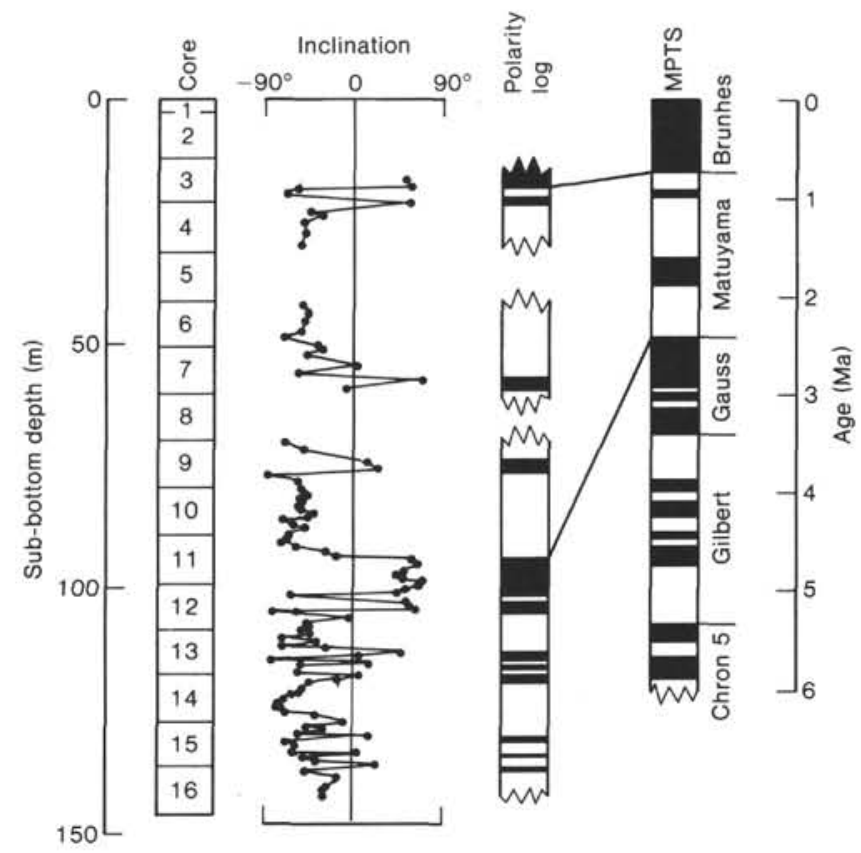

Figure 7. Results for Hole 608A samples after treatment at $10 \mathrm{mT}$. See Figure 4 caption for further explanation.

poor, as a result of very low intensities. Three short normal-polarity zones occur within the Matuyama Chronozone. The stratigraphically highest of these, just below the Brunhes Chronozone, is correlated with the Jaramillo Subchron. Correlation of the other two normal-polarity zones is uncertain, but the preferred correlation is that the lower of the two is the Olduvai Subchronozone and that the higher one is the short normal observed at other Leg 94 sites, possibly correlative with the Reunion Subchron.

The normal-polarity zone observed in Cores 608A-11 and $608 \mathrm{~A}-12$ is correlated with the top of the Gauss Chron. The base of the Gauss is ambiguous because of the quality of the data. It may be in Core $608 \mathrm{~A}-12$ or in the base of Core 608A-13.

\section{Site 609}

The sections with high accumulation rates cored in Hole 609 produced detailed polarity records for the last 4 m.y. Upper Miocene to Holocene sediments were recovered at this site. At Hole 609 the inclination record is continuous from Core 609-1 through Core 609-17. Cores $609-18$ through $609-25$ were plagued by poor recovery and coring disturbances; recovery improved in Cores 609-26 through 609-30, but then became poor again in Cores 609-31 to 609-33. A more complete record was obtained at Hole 609B, although Cores 609B-16 and 609B-18 had no recovery and below Core 609B-18 intermittent recovery problems produced gaps in the record.

Sediment accumulation rates of $60 \mathrm{~m} / \mathrm{m}$.y. or greater allowed the last five chronozones-the Brunhes, Matuyama, Gauss, Gilbert, and Chron 5-to be recognized; a number of short subchronozones are present within the Matuyama. These short polarity zones are present in Holes 609 and 609B and to a lesser extent in Hole 609C, giving them credibility as true polarity zones and indi- 
cating that they are not sampling artifacts or improperly demagnetized intervals. The Jaramillo and Olduvai subchronozones are present in both Hole 609 and Hole $609 \mathrm{~B}$, although the base of the Olduvai was not recognized in Hole 609B. Very short normal-polarity zones are present $13 \mathrm{~m}$ below the base of the Olduvai, $16 \mathrm{~m}$ above the top of the Olduvai, and $10 \mathrm{~m}$ below the base of the Jaramillo.

Construction of the composite polarity log was based primarily on the record from Hole 609B, down to the base of Core 609B-28. Below this level, intervals of no recovery and the observed depth-offset of polarity-zone boundaries in adjacent holes complicate the correlations. For instance, the Gauss/Gilbert reversal occurs at $239 \mathrm{~m}$ in Hole 609 but at $247 \mathrm{~m}$ in Hole 609B, a difference of $8 \mathrm{~m}$ between adjacent holes. For these reasons, correlation of the polarity zones beneath the Gauss is difficult. The preferred correlations with the time scale are shown in Figure 8.

\section{Site 610}

Six holes were cored at Site 610, situated on the Feni Ridge sediment drift; lower Miocene to Holocene sediments were recovered. Holes $610,610 \mathrm{~A}, 610 \mathrm{~B}$, and $610 \mathrm{C}$ were cored on the crest of a sediment wave and Holes $610 \mathrm{D}$ and $610 \mathrm{E}$ were cored in the adjacent wave trough. Paleomagnetic samples were taken from each of the holes, enabling the development of a stratigraphy which helped monitor the differences in accumulation rate between holes.

The results from Holes 610, 610A, 610B, and 610C are presented in Figure 9, where the correlations of the polarity $\log$ with the time scale are also indicated. Because of the significant offset of reversal boundaries between holes, the composite log is approximate, and the depths of the polarity boundaries are given in the Appendix.

In general, the results from the upper $150 \mathrm{~m}$ at this site are easily correlatable with the time scale. Below $150 \mathrm{~m}$ sub-bottom, however, very weak magnetizations cause the inclination records to be noisier. The offset between holes causes correlations between Holes 610 and $610 \mathrm{~A}$ to be of little value in correlating the observed polarity zones with the time scale.

The data from the two deep sections recovered at this site $(610,636-735 \mathrm{~m}$, and $610 \mathrm{E}, 260-330 \mathrm{~m})$ are difficult to interpret because of the moderate quality of the data and the lack of sequences long enough to provide a unique polarity record. The preferred correlations of these sections with the time scale are indicated in Figures 9 and 10.

The inclination record in Cores 19 through 26 from Hole 610 contains sampling gaps which (combined with the weak intensities) make it difficult to correlate with the time scale on the basis of the polarity sequences alone. Using shipboard biostratigraphic results, this sequence was correlated with Chrons C5B and C5C, the three normal-polarity zones in Cores $610-22$ through $610-26$ correlating with the three normal chrons in Chron $\mathrm{C} 5 \mathrm{C}$, on the basis of shipboard biostratigraphic results (see magnetobiostratigraphy synthesis chapter, this volume). But subsequent results from studies of planktonic foraminifers, diatoms, and calcareous nannofossils all suggest that this interval should be approximately one million years older than the original correlation would have indicated.

An alternative interpretation correlates the three normal magnetozones with Chrons C5D, C5E, and C6, with the upper portion of this interval correlated with Chron C5C. This pick appears to fit the biostratigraphic data much better, and is the one shown in Figure 9 and given in the Appendix.

For Hole $610 \mathrm{E}$, coring disturbances and weakly magnetized samples make interpretation of the record difficult, since many of the polarity zones are represented by only one sample. Resampling of this interval on shore yielded samples below the noise level of the cryogenic magnetometer at the Lamont-Doherty lab. Although the samples measured aboard ship were weak, they were above the noise level of the spinner magnetometer. It is unclear what caused the decay of the remanence of these cores between coring and shore-based measurement; only the shipboard measurements are shown in Figure 10.

Two interpretations are possible for this interval; both correlate the normal-polarity zone in Cores $610 \mathrm{E}-6$ and 610 E-7 with Chron 7 . The first would put the normal in the top of Core $610 \mathrm{E}-3$, correlative with the normal chron in Chron 6, whereas the second would place the normal zone in the top of Core $610 \mathrm{E}-5$, correlative with the Chron 6 normal, and the normal-polarity zones in Cores $610 \mathrm{E}-2$ and $610 \mathrm{E}-3$ would correlate with the Chron 5 normals.

Comparison of the nannofossil datums in this hole, particularly the first occurrence and last occurrence of D. quinqueramus (see Takayama and Sato, this volume), with results reported by Mazzei et al. (1979) for Site 397 in the eastern North Atlantic, suggest that sediment in Cores $610 \mathrm{E}-1$ and $610 \mathrm{E}-2$ (last occurrence of D. quinqueramus) may be correlative with Chron 5 . Unfortunately, the paleomagnetic data for this interval do not allow a definitive correlation based solely on the polarity sequence. The nannofossil data, however, support the second correlation, just discussed, which is shown in Figure 10.

\section{Site 611}

Like Site 610, Site 611 comprises six holes drilled on a sediment wave crest and trough situated on the Gardar Ridge sediment drift. Holes 611, 611A, 611D, and 611E were cored on the wave crest and $611 \mathrm{~B}$ and $611 \mathrm{C}$ were cored in the wave trough.

The results from the wave-crest holes are presented in Figure 11. Upper Pliocene to Holocene sediment was cored in these holes. Relatively high sediment accumulation rates, together with relatively low $\mathrm{CaCO}_{3}$ contents (compared with cores from the previous Leg 94 sites), resulted in the acquisition of detailed polarity records, even through intervals which at previous sites were too weakly magnetized to be measured. The composite polarity log and its correlation with the time scale are shown in Figure 11. Holes 611 and $611 \mathrm{~A}$ penetrated the top of the Gauss Chronozone; the record from Hole 611D 

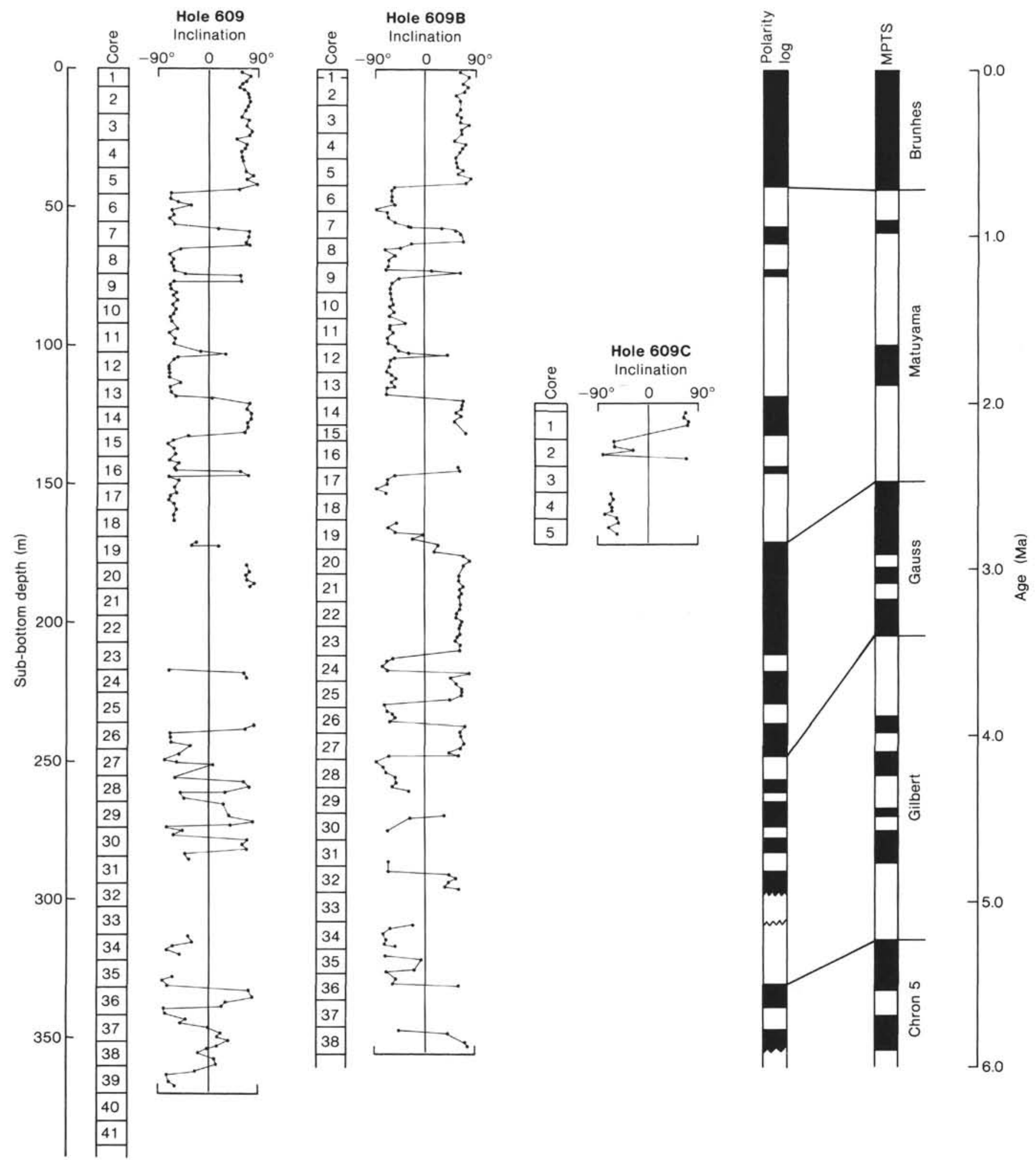

Figure 8. Results for Site 609 samples after treatment at $10 \mathrm{mT}$. See Figure 4 caption for further explanation.

starts in the top of the Gauss and ends in a short normal zone in the Gilbert, correlated with the Cochiti Subchron. The magnetostratigraphy of the crest holes therefore indicates that the cores span from the Quaternary back to more than $3.9 \mathrm{Ma}$.
Of the holes cored in the wave trough, samples were taken only from Hole $611 \mathrm{C}$, from which middle Miocene to Holocene sediments were recovered. Coring in this hole was plagued by very poor recovery and drilling disturbance in the cores, resulting in a record marked by 


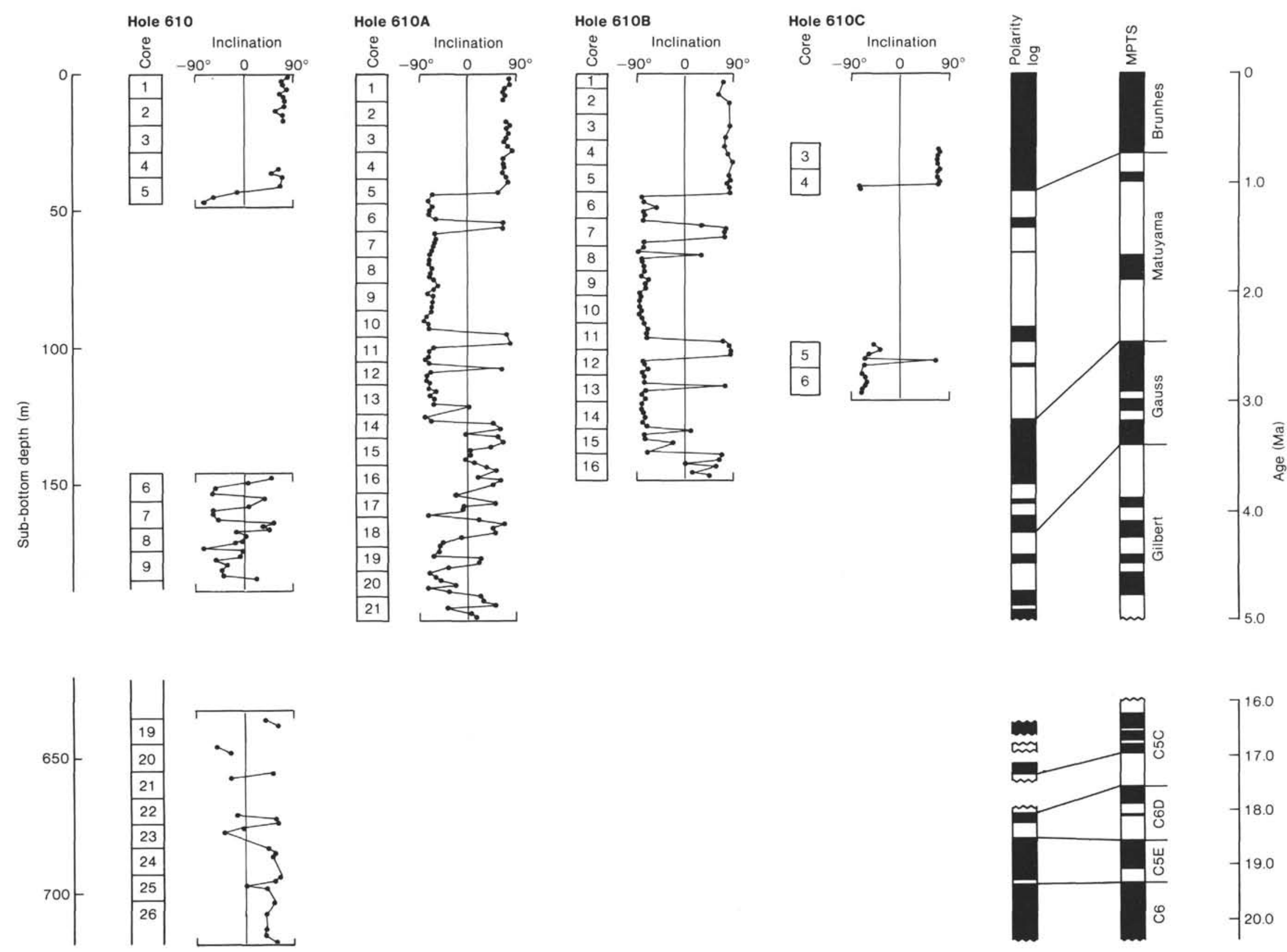

Figure 9. Results for samples from the four holes cored on the sediment wave crest at Site 610, after treatment at $10 \mathrm{mT}$. See Figure 4 caption for further explanation. 


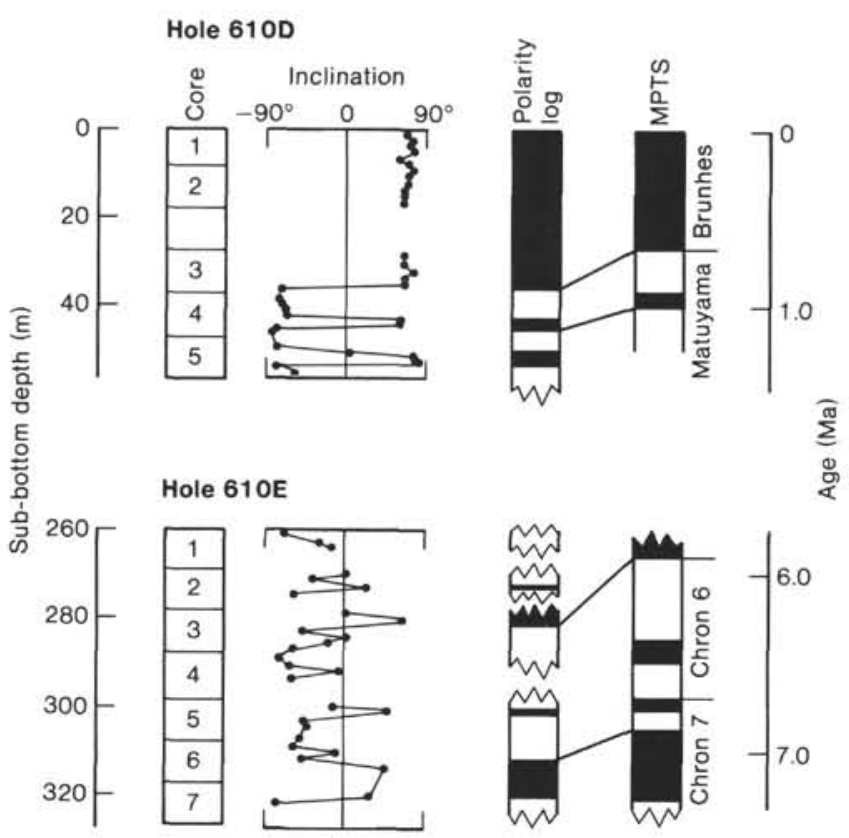

Figure 10. Results for samples from the sediment-wave trough holes drilled at Site 610 , after treatment at $10 \mathrm{mT}$. See Figure 4 caption for further explanation. gaps in the data. In spite of this, however, the polarity sequence plotted in Figure 12 was obtained, and the two long segments of continuous data, for Cores $611 \mathrm{C}-1$ to $611 \mathrm{C}-16$ and $611 \mathrm{C}-38$ to $611 \mathrm{C}-43$, allow portions of the reversal sequence to be correlated with the time scale as indicated.

The interval between these sequences contains enough isolated reversals to allow parts to be correlated with the time scale. For example, the normal-polarity zone in Cores $611 \mathrm{C}-18$ and $611 \mathrm{C}-19$ most likely represents the base of the Kaena Subchronozone and the top of the Mammoth Subchronozone. Farther downcore, the normal-polarity zone in Core $611 \mathrm{C}-26$ probably correlates with the Nunivak Subchron. The sequences recorded in Cores $611 \mathrm{C}-44$ through $611 \mathrm{C}-47$ are more difficult to interpret because of the long washdown intervals separating these cores. The sediment in Cores $611 \mathrm{C}-46$ to $611 \mathrm{C}-47$ may be correlative with Chron 10, on the basis of nannofossil zonation placing Core 611C-47 in Zone NN10 (Takayama and Sato, this volume) and the correlation of this zone with Chron 10 elsewhere (Berggren, Kent, and Van Couvering, in press).

\section{DISCUSSION}

The magnetostratigraphy of Leg 94 sediments is summarized in Figure 13, where the composite sections rep-

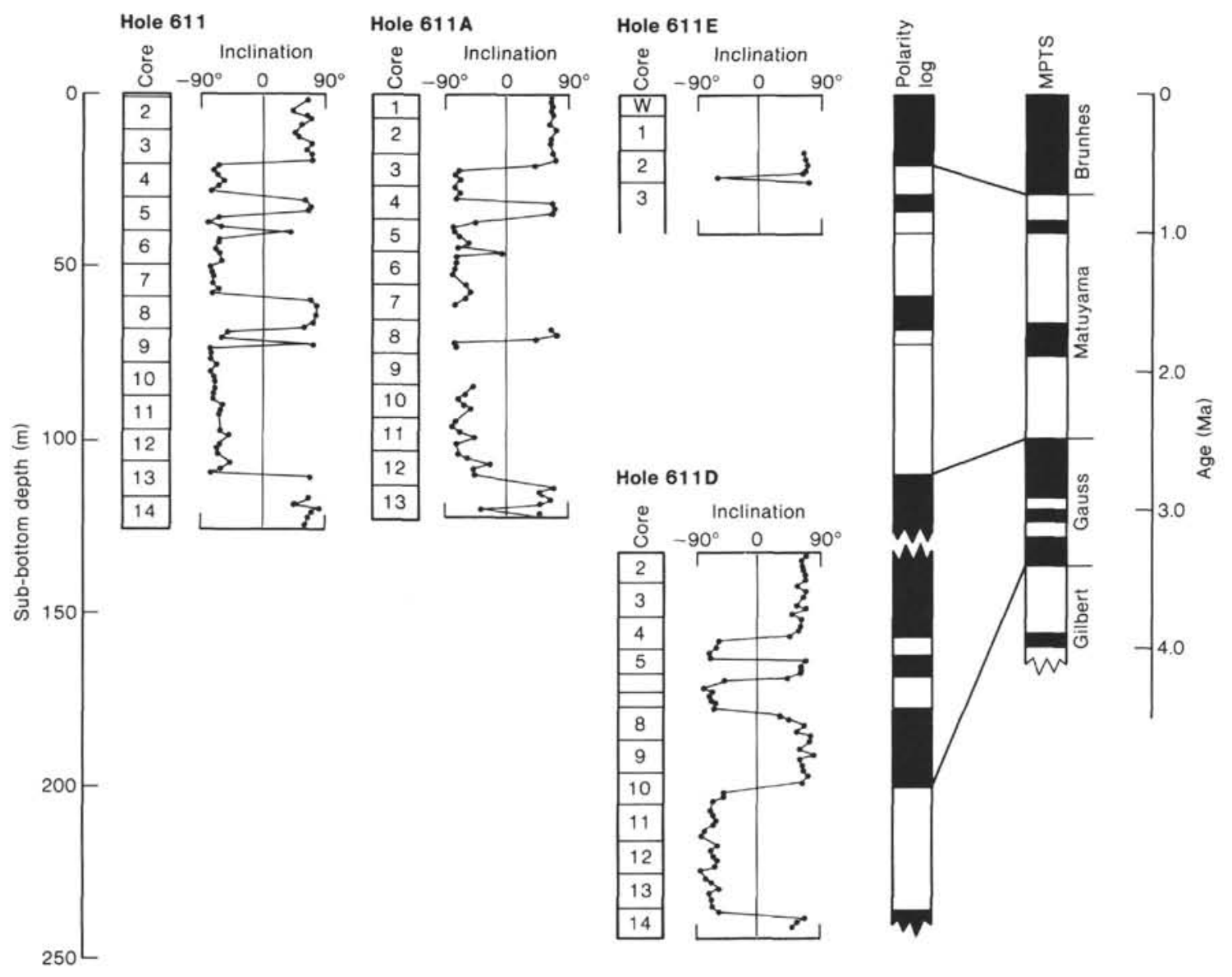

Figure 11. Results for samples from the wave crest holes cored at Site 611 , after treatment at $10 \mathrm{mT}$. See Figure 4 caption for further explanation. 


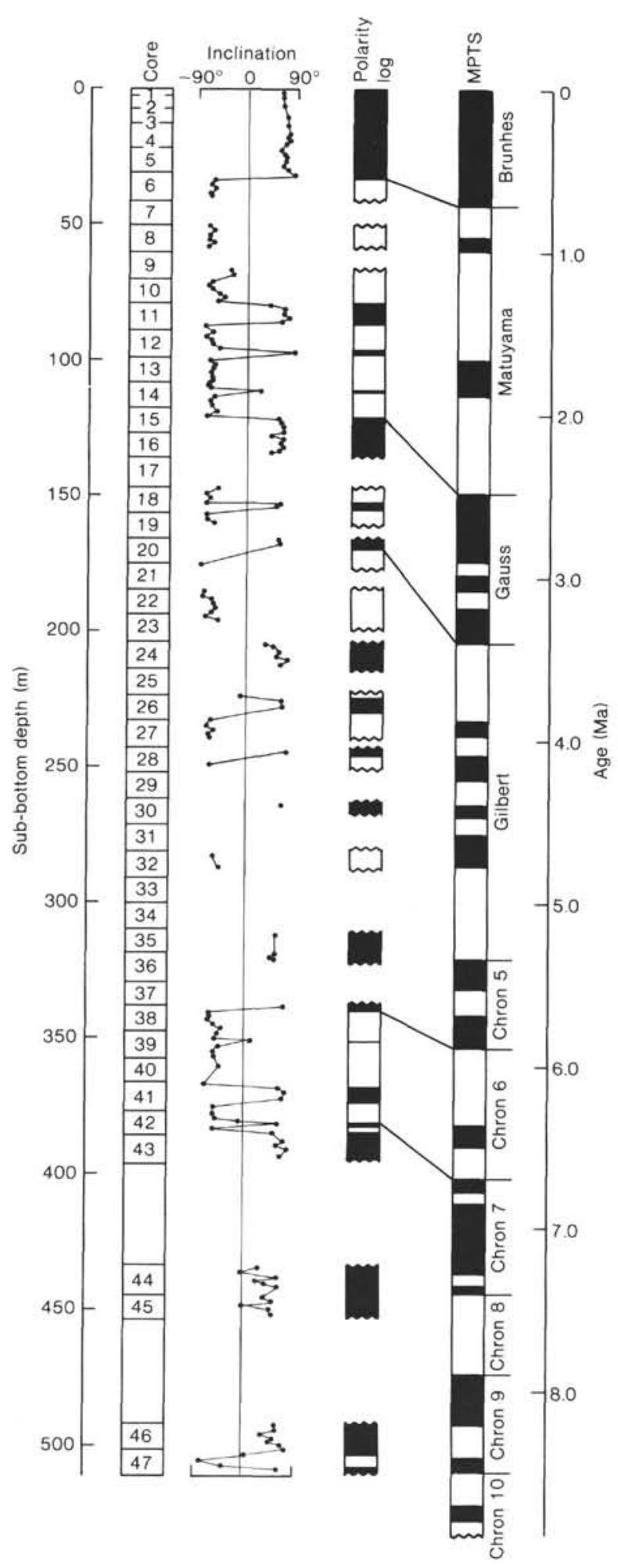

Figure 12. Results for Hole $611 \mathrm{C}$ samples after treatment at $10 \mathrm{mT}$. See Figure 4 caption for further explanation.

resentative of each site (for the uppermost $250 \mathrm{~m}$ ) are correlated with the magnetic polarity time scale. In addition to establishing a chronology for these sediments by determining the depths of independently dated geomagnetic reversals, these records from high-accumulation rate cores contain detailed records of geomagnetic reversal history for the last 4 m.y. Of particular interest are the four very short zones observed in records from more than one hole. Several very short polarity chrons have been reported in the literature, although most of these have not been generally accepted, because they have not been observed in geographically distributed localities and have not been seen in different paleomagnetic recorders (i.e., sediments and igneous rocks).

Two of the short polarity zones in the Leg 94 records occur at several sites (and in multiple holes at some of those sites), satisfying the requirement of geographic distribution. In addition, these polarity zones appear to correlate with polarity chrons previously suggested by other workers. The youngest of these two short normals, which occurs within the Matuyama Chronozone, is present just beneath the Jaramillo Subchronozone in a total of seven holes, and is represented at five of the six sites. The older occurs beneath the Olduvai Subchron in nine holes and is present at every site except 607 .

Ages of these two polarity zones may be estimated from their observed depths and the average sediment accumulation rate for each hole. The average accumulation rates during the Matuyama Chron are calculated using the ages and depths of the reversal boundaries for the last 2.47 m.y. The accumulation rate curves, however, show inflections near the base of the Jaramillo Subchronozone, indicating a change in the rate. Therefore, in determining ages for the normal-polarity zone just beneath the Jaramillo, accumulation rates were calculated using only the origin, the Brunhes/Matuyama, and the Jaramillo reversals. Ages for each polarity zone were then averaged in an attempt to eliminate possible errors caused by different sampling intervals and local variations in sediment accumulation rates.

The average ages of the upper and lower boundaries of the normal just beneath the Jaramillo Subchronozone, as determined from age estimates in seven holes, are 1.11 and $1.15 \mathrm{Ma}$. The maximum duration of this zone as estimated from Hole 609B, which had the highest accumulation rate $(63.36 \mathrm{~m} / \mathrm{m}$.y.), is $30,000 \mathrm{yrs}$. This estimate is based on the results from the shipboard sampling interval of $1.5 \mathrm{~m}$, and therefore is likely to be too large. Detailed sampling of this zone in Hole 609B sediment is currently underway, and a more tightly constrained estimate will be presented elsewhere.

The boundaries of the polarity zone below the Olduvai are given age estimates based on the average age of the boundaries in eight holes. This zone occurs in Hole $610 \mathrm{C}$, but the lack of other nearby reversals leaves the sediment accumulation rate relatively unconstrained, so this hole was not used in this average. The average ages for the upper and lower boundaries are 2.01 and $2.04 \mathrm{Ma}$. A maximum-duration estimate calculated from Hole 609B is 20,000 yrs.

The other two short polarity zones were each observed at only one site. In Holes 609 and 609B a short normal occurs above the Olduvai, whereas in Holes 607 and $607 \mathrm{~A}$ a short reversed-polarity zone is present within the upper portion of the Gauss Chronozone. Age estimates for these short zones of 1.39 and 1.41 and 2.65 and 2.70 $\mathrm{Ma}$, respectively, are obtained using the accumulation rates calculated for these holes. These two subchrono- 


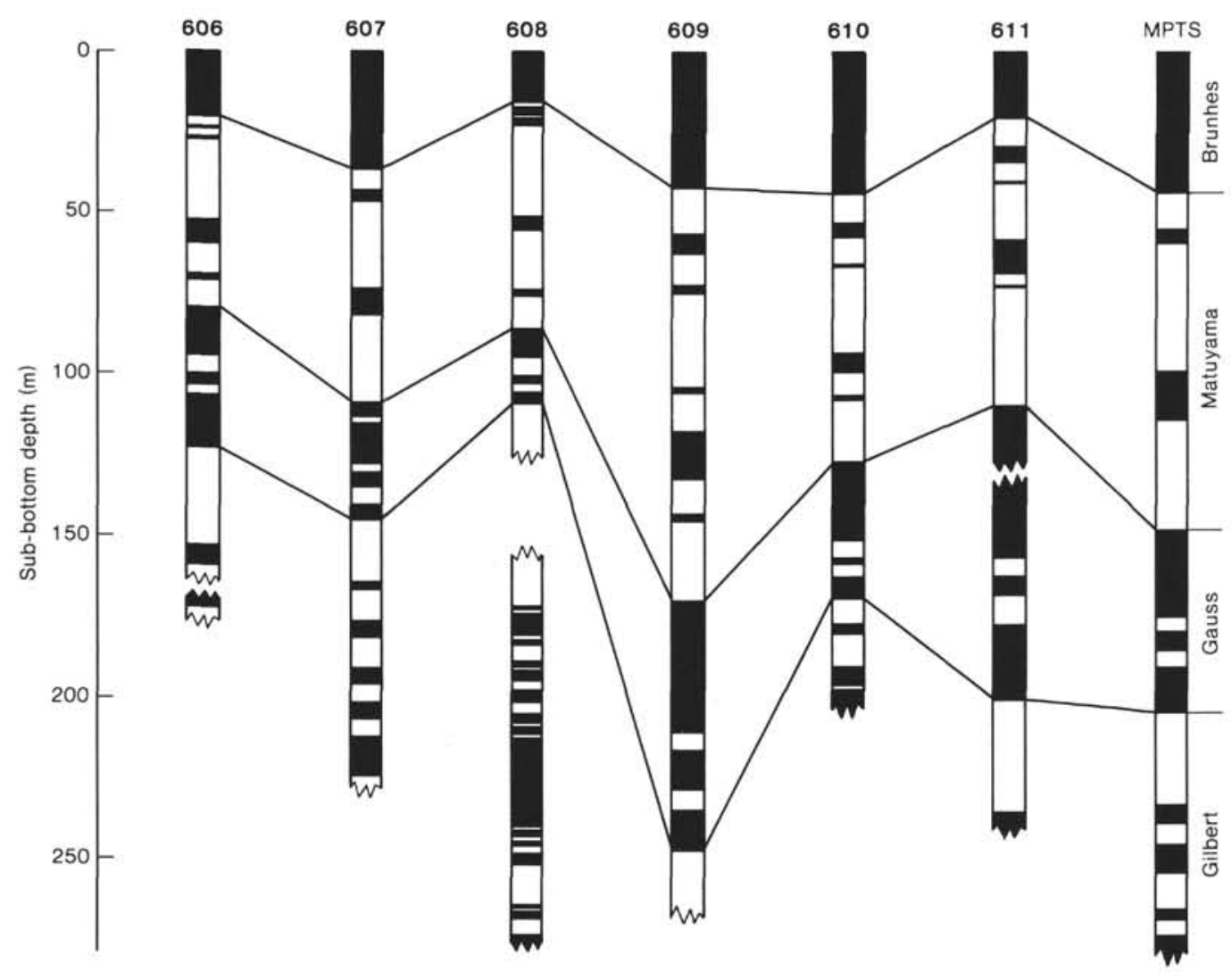

Figure 13. Composite polarity sections for the six Leg 94 sites, correlated with the magnetic polarity time scale.

zones were not observed in any other holes having an average sampling interval of one sample per 20,000 to 30,000 yrs. Therefore, if these are records of true geomagnetic field reversals, the subchrons probably lasted less than 20,000 yrs.

The short normal beneath the Jaramillo has a calculated age in excellent agreement with a radiometric age of $1.12 \mathrm{Ma}$, reported by Mankinen et al. (1978) for a normal-polarity zone located on Cobb Mountain, which they named the Cobb Mountain subchron (Event). They cite a number of reports of what probably correlates with the Cobb Mountain subchron in deep-sea cores (Kawai et al., 1977; Ninkovitch et al., 1966) and more recently this chron has been reported for samples from piston cores (Sueshi et al., 1979) and HPC cores (Kent and Spariosu, 1982; Shackleton et al., 1984). The existence of this chron is also supported by stacked marine magnetic anomaly profiles (Rea and Blakely, 1975). The data presented here strongly support the existence of a short normal-polarity geomagnetic subchron at approximately 1.1 Ma.

The normal subchronozone dated at $2.02 \mathrm{Ma}$ appears to correlate with the more firmly established Reunion Subchron (MacDougall and Chamalaun, 1966). This subchron has previously been suggested to consist of two short normal-polarity zones, but it is consistently observed as a single normal in the Leg 94 sediments.

The two other short polarity zones are more difficult to correlate with previously reported subchronozones. Tauxe et al. (1983) reported a normal-polarity subchronozone just above the Olduvai in the Vrica section in
Calabria which may correlate with the normal seen at Site 609. The correlation at the Vrica section was uncertain, however. Since these zones were observed only at single sites and not at the other high-accumulation-rate sites on this leg, they may represent very rapid field changes, which one would not expect to be detected except in sections where the accumulation rate was extremely high. Both of these zones, however, occur at intervals in which La Brecque et al. (1977) indicate the presence of short events or intensity fluctuations. These polarity zones therefore suggest that these tiny wiggles in the marine magnetic anomaly profiles are reversals instead of geomagnetic intensity variations.

\section{CONCLUSIONS}

The magnetic polarity records of 21 holes at the six Leg 94 sites are correlated with the geomagnetic polarity time scale derived from the seafloor-spreading magnetic anomaly pattern, and thereby provide an independent chronology for the Leg 94 sediments. The magnetostratigraphy of the sites presented in this chapter establishes a time framework for biostratigraphic, paleoclimatic, tectonic, and other studies. A correlatable magnetostratigraphy of the upper 150 to $200 \mathrm{~m}$ of sediment was obtained through study of sections cored with the HPC; in addition, material cored with the XCB corer provided material suitable for paleomagnetic study and allowed records of older polarity sequences to be obtained. In particular, at Hole 608 a nearly continuous polarity record from Brunhes to middle upper Oligocene was obtained, together with a less complete record extending 
down into the upper Eocene. Likewise, partial sections in the Miocene were recovered from Sites 610 and 611 .

Shipboard paleomagnetic measurements allowed determination of the polarity sequence while on site and therefore facilitated drilling decisions. Such information proved useful in determining the depth offsets between adjacent holes so that coring adjustments could be made to core intervals not recovered at the previous holes (see Ruddiman et al., this volume).

The polarity records from these high-accumulationrate cores provide detailed records of geomagnetic reversal history. A number of short polarity subchronozones were identified in several holes. Two short normal subchronozones within the Matuyama were recognized in addition to the Jaramillo and Olduvai. These two short events are represented in several holes at multiple sites, supporting the interpretation of these polarity zones as records of geomagnetic behavior. These zones are correlated with the Cobb Mountain and Reunion subchrons, and the ages of these subchronozones are in close agreement with the radiometric ages previously reported for them. This is evidence supporting the existence of two short normal-polarity subchrons within the Matuyama which provide useful magnetostratigraphic markers in sections where the sediment accumulation rate was high.

\section{ACKNOWLEDGMENTS}

We thank Dennis Kent, Ken Miller, Lisa Tauxe, and two anonymous reviewers for their comments and discussions, which improved this work. Special thanks are extended to the Leg 94 co-chiefs, Bill Ruddiman and Rob Kidd, and to the shipboard party, for making Leg 94 an enjoyable and rewarding cruise. Ellen Thomas and Paula Weiss provided invaluable assistance in sampling. This work was supported by NSF Grant OCE83-00356. Lamont-Doherty Geological Observatory Contribution No. 3934.

\section{REFERENCES}

Alvarez, W., Arthur, M. S., Fisher, A. F., Lowrie, W., Napoleone, G., et al., 1977. Type section for the Late Cretaceous-Paleocene reversal time scale. Geol. Soc. Am. Bull., 88:367-389.

Berggren, W. A., Kent, D. V., and Flynn, J. J., in press. Paleogene geochronology and chronostratigraphy. In Snelling, N. J. (Ed.), Geochronology and the Geologic Time Scale. Geol. Soc. London Mem.

Berggren, W. A., Kent, D. V., and Van Couvering, in press. Neogene geochronology and chronostratigraphy. In Snelling, N. J. (Ed.), Geochronology and the Geologic Time Scale. Geol. Soc. London Mem.

Blakely, R. J., 1974. Geomagnetic reversals and crustal spreading rates during the Miocene. J. Geophys. Res., 79:297-300.

Butler, R. F., and Coney, P. J., 1981. A revised timescale for the Paleocene and early Eocene and implications for Pacific Plate motion. Geophys. Res. Lett., 8:301-304.

Cande, S. C., and La Brecque, J. L., 1974. Behavior of the Earth's paleomagnetic field from small scale marine magnetic anomalies. Nature, 246:26-28.

Cox, A., 1982. Magnetic reversal timescale. In Harland, W. B., Cox, A., Llewellyn, P. G., et al. (Eds.), A Geologic Time Scale: Cambridge (Cambridge Univ, Press).

Hedberg, H. D., Salvaldor, A., and Opdyke, N. D., 1979. Magnetostratigraphic units-A supplementary chapter of the ISSC International Stratigraphic Guide. Geology, 7:578-583.

Heirtzler, J. R., Dickson, G. O., Herron, E. M., Pitman, W. C., III, and Le Pichon, X., 1968. Marine magnetic anomalies, geomagnetic field reversals and motions of the ocean floor and continents. $J$. Geophys. Res., 73:2119-2136.

Hsü, K. J., La Brecque, J. L., Kawai, N., Yaskawa, K., and Nakajima, T., 1984. Numerical ages of Cenozoic biostratigraphic datum levels: Results of Leg 73 drilling. Geol. Soc. Am. Bull., 95:863-876.
Kawai, N., Hsü, K. J., La Brecque, J. L., Percival, S. F., Wright, R. C., Gombos, A. M., et al., 1977. Paleomagnetic study of deep-sea sediments from the Melanesia Basin. J. Geomag. Geoelec,, 29:211223.

Kent, D. V., and Spariosu, D. J., 1982. Magnetostratigraphy of Caribbean Site 502 hydraulic piston cores. In Prell, W. L., Gardner, J. V., et al., Init. Repts. DSDP, 68: Washington (U.S. Govt. Printing Office), 419-434.

Khan, M. J., Kent, D. V., and Miller, K. G., 1985. Magnetostratigraphy of Oligocene to Pleistocene sediments of DSDP Leg 82. In Bougault, H., Cande, S. C., et al., Init. Repts. DSDP, 82: Washington (U.S. Govt. Printing Office), 385-392.

La Brecque, J. L., Hsü, K. J., Carman, M. F., Karpoff, A. M., McKenzie, J., 1983. DSDP Leg 73: Contributions to Paleogene stratigraphy in nomenclature, chronology and sedimentation rates. Paleogeogr., Paleoclimatol., Paleoecol., 42:91-125.

La Brecque, J. L., Kent, D. V., and Cande, S. C., 1977. Revised magnetic polarity time scale for Late Cretaceous and Cenozoic time. Geology, 5:330-335.

MacDougall, I., and Chamalaun, F. H., 1966. Geomagnetic polarity scale of time. Nature, 212:1415-1418.

McMillen, K. J., Warme, J. E., and Hemman, E. H., 1977. An electro-osmotic knife for slicing large box cores. J. Sediment. Petrol., 47:864-867.

Mankinen, E. A., Donnilly-Nolan, J. M., Grommé, C. S., 1978. Geomagnetic polarity event recorded at 1.1 m.y. B.P. on Cobb Mountain, Clear Lake Volcanic Field, California. Geology, 6:653-656.

Mazzei, E., Raffi, I., Rio, D., Hamilton, N., and Cita, M. B., 1979. Calibration of late Neogene calcareous datum planes with the paleomagnetic record of Site 397, and correlation with Moroccan and Mediterranean sections. In von Rad, U., Ryan, W. B. F., et al., Init. Repts. DSDP, 47, Pt. 1: Washington (U.S. Govt. Printing Office), $375-389$.

Miller, K. G., Aubry, M.-P., Khan, M. J., Melillo, A. J., Kent, D. V., and Berggren, W. A., 1985. Oligocene to Miocene bio-, magneto-, and isotopic stratigraphy of the western North Atlantic. Geology, 13:257-261.

Ninkovitch, D., Opdyke, N. D., Heezen, B. C., and Foster, J. H., 1966. Paleomagnetic stratigraphy, rates of deposition and tephrachronology in North Pacific deep-sea sediment cores. Earth Planet. Sci. Lett., 1:476-492.

Rea, D. K., and Blakely, R. J., 1975. Short-wavelength magnetic anomalies in a region of rapid seafloor spreading. Nature, 255:126-128.

Ryan, W. B. F., Cita, M. B., Dreyfus Rawson, M., Burckle, L. H., and Saito, T., 1974. A paleomagnetic assignment of Neogene stage boundaries and the development of isochronous datum planes between the Mediterranean, the Pacific, and Indian oceans in order to investigate the response of the world ocean to the Mediterranean "salinity crisis." Riv. Ital. Paleontol., 80:631-688.

Shackleton, N., Backman, J., Zimmerman, H., Kent, D. V., Hall, M. A., et al., 1984. Oxygen isotope calibration of the onset of icerafting in DSDP Site 552A: History of glaciation in the North Atlantic Region. Nature, 307:620-623.

Sturm, M., and Malter, A., 1972. The electro-osmotic guillotine, a new device for core splitting, J. Sediment. Petrol., 42:987-989.

Sueshi, T., Sato, T., Kawai, N., and Kobayoshi, K., 1979. Short geomagnetic polarity episodes in the Matuyama Epoch. Phys. Earth Planet. Inter., 19:1-11.

Tauxe, L., Opdyke, N. D., Pasini, G., and Elmi, C., 1983. Age of the Plio-Pleistocene boundary in the Vrica section, southern Italy. $\mathrm{Na}$ ture, 304:125-129.

Theyer, F., and Hammond, S. R., 1974. Paleomagnetic polarity sequence and radiolarian zones, Brunhes to polarity Epoch 20. Earth Planet. Sci. Lett., 22:307-319.

Weaver, P. P. E., and Schultheiss, P. J., 1983. Detection of repenetration and sediment disturbances in open barrel gravity cores. J. Sediment. Petrol., 53:1-6.

Zijderveld, J. D. A., 1967. AC demagnetization of rocks: Analysis of results. In Collinson, D. W., Creer, K. M., and Runcorn, S. K. (Eds.), Methods in Paleomagnetism: New York (Elsevier), pp. 254286.

Date of Initial Receipt: 12 November 1984

Date of Acceptance: 4 April 1985 
APPENDIX

Reversal Boundaries at Leg 94 Sites

\begin{tabular}{|c|c|c|c|c|}
\hline \multicolumn{2}{|c|}{$\begin{array}{c}\text { Reversal } \\
\text { boundaries }\end{array}$} & $\begin{array}{l}\text { Age } \\
(\mathrm{Ma})\end{array}$ & $\begin{array}{l}\text { Core-Section, } \\
\text { level }(\mathrm{cm})\end{array}$ & $\begin{array}{l}\text { Sub-bottom } \\
\text { depth }(\mathrm{m})\end{array}$ \\
\hline \multicolumn{5}{|c|}{ Site 606} \\
\hline \multicolumn{5}{|l|}{ Hole 606} \\
\hline \multicolumn{2}{|l|}{ Brunhes/Matuyama } & 0.73 & $3-5,128 / 3-6,6$ & $19.69 / 19.97$ \\
\hline \multirow[t]{2}{*}{ Jaramillo } & (top) & 0.91 & $4-1,120 / 4-2,35$ & $23.21 / 23.86$ \\
\hline & (bottom) & 0.98 & $4-2,35 / 4-2,97$ & $23.86 / 24.48$ \\
\hline \multirow[t]{2}{*}{ Cobb Mtn. } & (top) & - & $4-4,35 / 4-4,97$ & $26.86 / 27.48$ \\
\hline & (bottom) & - & $4-4,97 / 4-5,35$ & $27.48 / 28.98$ \\
\hline \multirow[t]{2}{*}{ Olduvai } & (top) & 1.66 & $7-2,35 / 7-2,97$ & $52.66 / 53.28$ \\
\hline & (bottom) & 1.88 & $7-6,35 / 7-6,97$ & $58.66 / 59.28$ \\
\hline \multirow[t]{2}{*}{ Reunion } & (top) & & $8-6,35 / 8-6,97$ & $68.26 / 70.28$ \\
\hline & (bottom) & & $8-6,97 / 9-2,97$ & $70.28 / 72.48$ \\
\hline Matuyama/Gauss & (top) & 2.47 & $9-6,97 / 10-1,97$ & $78.48 / 80.58$ \\
\hline \multirow[t]{2}{*}{ Kaena } & (top) & 2.92 & $11-3,97 / 11-4,97$ & $93.18 / 94.68$ \\
\hline & (bottom) & 2.99 & $12-1,97 / 12-2,97$ & $99.68 / 101.18$ \\
\hline \multirow[t]{2}{*}{ Mammoth } & (top) & 3.08 & $12-3,97 / 12-4,97$ & $102.68 / 104.18$ \\
\hline & (bottom) & 3.18 & $12-5,97 / 12-6,85$ & $105.68 / 107.06$ \\
\hline Gauss/Gilbert & (top) & 3.40 & $14-3,97 / 14-4,97$ & $121.68 / 123.18$ \\
\hline \multirow[t]{2}{*}{ Cochiti } & (top) & 3.88 & $17-4,96 / 17-5,96$ & $151.97 / 153.47$ \\
\hline & (bottom) & 3.97 & $18-1,97 / 18-3,110$ & $157.08 / 160.21$ \\
\hline
\end{tabular}

Hole 606A

$\begin{array}{lrrcc}\begin{array}{l}\text { Brunhes/Matuyama } \\ \text { Jaramillo }\end{array} & & 0.73 & 3-4,20 / 3-4,55 & 19.90 / 20.25 \\ & \text { (top) } & 0.91 & 3-5,97 / 3-5,127.5 & 22.18 / 22.48 \\ \text { Olduvai } & \text { (bottom) } & 0.98 & 3-6,6 / 4-1,20 & 22.74 / 25.01 \\ \text { Cochiti } & \text { (top) } & 1.88 & 7-3,97 / 7-3,140 & 57.58 / 58.01 \\ & \text { (bottom) } & 3.97 & 17-1,97 / 17-2,97 & 150.58 / 152.08 \\ \text { Nunivak } & \text { (bottom) } & 4.24 & 19-2,97 / 17-6,97 & 156.58 / 158.08 \\ & & & & \end{array}$

Site 607

Hole 607

\begin{tabular}{|c|c|c|c|c|}
\hline Brunhes & & 0.73 & $4-6,97 / 5-1,90$ & $33.68 / 35.71$ \\
\hline \multirow[t]{2}{*}{ Jaramillo } & (top) & 0.91 & $5-5,97 / 5-6,97$ & $41.78 / 43.28$ \\
\hline & (bottom) & 0.98 & $6-1,97 / 6-2,97$ & $45.38 / 46.88$ \\
\hline \multirow[t]{2}{*}{ Olduvai } & (top) & 1.66 & $8-6,97 / 9-1,97$ & $72.08 / 74.18$ \\
\hline & (bottom) & 1.88 & $9-6,97 / 9-7,25$ & $81.68 / 82.46$ \\
\hline Matuyama/Gauss & & 2.47 & $12-5,97 / 12-6,106$ & $108.98 / 110.57$ \\
\hline \multirow[t]{2}{*}{ Kaena } & (top) & 2.92 & $14-4,97 / 14-5,97$ & $126.68 / 128.18$ \\
\hline & (bottom) & 2.99 & $14-6,97 / 15-1,97$ & $129.68 / 131.78$ \\
\hline \multirow[t]{2}{*}{ Mammoth } & (top) & 3.08 & $15-2,97 / 15-3,124$ & $133.28 / 135.05$ \\
\hline & (bottom) & 3.18 & $15-5,97 / 15-6,97$ & $137.78 / 139.28$ \\
\hline Gauss/Gilbert & & 3.40 & $16-3,97 / 16-4,97$ & $144.38 / 145.88$ \\
\hline \multirow[t]{2}{*}{ Cochiti } & (top) & 3.88 & $19-4,97 / 19-6,72$ & $174.68 / 177.41$ \\
\hline & (bottom) & 3.97 & $20-2,97 / 20-3,97$ & $181.28 / 182.78$ \\
\hline \multirow[t]{2}{*}{ Nunivak } & (top) & 4.10 & $21-2,97 / 21-3,97$ & $190.88 / 192.38$ \\
\hline & (bottom) & 4.24 & $21-4,97 / 21-5,97$ & $193.88 / 195.38$ \\
\hline \multirow[t]{2}{*}{$\mathrm{Cl}$} & (top) & 4.40 & $22-2,97 / 22-6,97$ & $200.48 / 206.48$ \\
\hline & (bottom) & 4.47 & $22-6,97 / 23-1,97$ & $206.48 / 208.58$ \\
\hline \multirow[t]{2}{*}{$\mathrm{C} 2$} & (top) & 4.57 & $23-1,97 / 23-4,97$ & $208.58 / 213.08$ \\
\hline & (bottom) & 4.77 & $24-4,123 / 24-5,110$ & $222.94 / 224.31$ \\
\hline \multicolumn{5}{|l|}{ Hole $607 \mathrm{~A}$} \\
\hline Brunhes & & 0.73 & $5-4,97 / 5-5,25$ & $35.98 / 37.76$ \\
\hline \multirow[t]{2}{*}{ Jaramillo } & (top) & 0.91 & $6-3,45 / 6-3,97$ & $43.56 / 44.08$ \\
\hline & (bottom) & 0.98 & $6-5,144 / 6-6,40$ & $47.55 / 48.00$ \\
\hline \multirow[t]{2}{*}{ Olduvai } & (top) & 1.66 & $9-5,97 / 9-5,145$ & $75.88 / 76.36$ \\
\hline & (bottom) & 1.88 & $10-4,97 / 10-5,97$ & $83.98 / 85.48$ \\
\hline Matuyama/Gauss & & 2.47 & $13-3,97 / 13.4,97$ & $111.28 / 112.78$ \\
\hline \multirow[t]{2}{*}{ Kaena } & (top) & 2.92 & $15-2,100 / 15-3,97$ & $129.01 / 130.48$ \\
\hline & (bottom) & 2.99 & $15-4,97 / 15-5,97$ & $131.98 / 133.48$ \\
\hline \multirow[t]{2}{*}{ Gauss/Gilbert } & & 3.40 & $18-1,97 / 18-2,97$ & $150.38 / 151.88$ \\
\hline & & \multicolumn{2}{|c|}{ Site 608} & \\
\hline \multicolumn{5}{|l|}{ le 608} \\
\hline Brunhes & & 0.73 & $2-6,98 / 3-1,98$ & $15.49 / 17.59$ \\
\hline \multirow[t]{2}{*}{ Jaramillo } & (top) & 0.91 & $3-1,98 / 3-2,98$ & $17.59 / 19.09$ \\
\hline & (bottom) & 0.98 & $3-3,98 / 3-4,88$ & $20.59 / 21.99$ \\
\hline \multirow[t]{2}{*}{ Cobb Mtn. } & (top) & - & $3-4,88 / 3-5,98$ & $21.99 / 23.59$ \\
\hline & (bottom) & - & $3-5,98 / 3-6,98$ & $23.59 / 25.09$ \\
\hline \multirow[t]{2}{*}{ Olduvai } & (top) & 1.66 & $6-4,98 / 6-5,98$ & $50.89 / 52.39$ \\
\hline & (bottom) & 1.88 & $6-6,98 / 7-1,98$ & $53.89 / 55.99$ \\
\hline \multirow{3}{*}{$\begin{array}{l}\text { Matuyama/Gauss } \\
\text { Kaena }\end{array}$} & & 2.47 & $10-1,98 / 10-2,98$ & $84.79 / 86.29$ \\
\hline & (top) & 2.92 & $10-6,98 / 11-1,98$ & $92.29 / 94.39$ \\
\hline & (bottom) & 2.99 & $11-5,98 / 11-6,98$ & $100.39 / 101.89$ \\
\hline
\end{tabular}

Appendix (continued).

\begin{tabular}{llll}
\hline $\begin{array}{c}\text { Reversal } \\
\text { boundaries }\end{array}$ & $\begin{array}{c}\text { Age } \\
(\mathrm{Ma})\end{array}$ & $\begin{array}{c}\text { Core-Section, } \\
\text { level }(\mathrm{cm})\end{array}$ & $\begin{array}{c}\text { Sub-bottom } \\
\text { depth }(\mathrm{m})\end{array}$ \\
\hline & Site 608 (Cont.)
\end{tabular}

Hole 608 (Cont.)

$\begin{array}{lr}\text { Mammoth } \quad \begin{array}{r}\text { (top) } \\ \text { (bottom) }\end{array} & 3.08 \\ & 3.18 \\ \text { Gauss/Gilbert } & 3.40 \\ \text { Chron 6/Chron 7 } & 6.70 \\ \text { Chron 7/Chron 8 } & 7.41 \\ \text { Chron 8/Chron 9 } & 7.90 \\ \text { Chron 9/Chron 10 } & 8.50 \\ \text { Chron 10/Chron C5 } & 8.92 \\ \text { Chron C5/Chron C5A } & 11.55 \\ \text { Chron C5A/Chron C5AA } & 12.83 \\ \text { Chron C5AA/Chron C5AB } & 13.20 \\ \text { Chron C5AD/Chron C5B } & 14.87 \\ \text { Chron C5B/Chron C5C } & 16.22 \\ \text { Chron C5C/Chron C5D } & 17.57 \\ \text { Chron C5D/Chron C5E } & 18.56 \\ \text { Chron C5E/Chron C6 } & 19.35 \\ \text { Chron C6/Chron C6A } & 20.88 \\ \text { Chron C6A/Chron C6AA } & 21.90 \\ \text { Chron C6AA/Chron C6B } & 22.57 \\ \text { Chron C6B/Chron C6C } & 23.27 \\ \text { Chron C8/Chron C9 } & 28.15\end{array}$

$12-1,65 / 12-1,98$ $12-3,98 / 12-4,98$ $12-5,30 / 12-5,98$ $19-3,98 / 19-4,25$ 20-5, 25/20-5, 98 $21-3,25 / 21-3,87$ $22-4,25 / 22-4,98$ 23-2, $98 / 23-3,98$ $29-1,98 / 29-2,30$ $31-3,90 / 31-4,24$ $32-5,106 / 33-1,50$ $34-5,88 / 34-6,94$ $36-2,128 / 36-3,6$ $37-4,96 / 37-5,10$ $38-4,25 / 38-4,40$ $39-3,50 / 39-4,126$ $42-2,32 / 42-3,33$ $42-4,16 / 43-1,34$ $44-2,24 / 44-2,102$ $45-6,123 / 46-1,6$ Chron $\mathrm{C} 8 / \mathrm{Chron} \mathrm{C} 9$

$48-3,138 / 48-4,33$

$103.66 / 103.99$ $106.99 / 108.49$ $109.31 / 109.99$ $170.09 / 170.86$ $181.96 / 182.69$ $188.56 / 189.18$ $199.66 / 200.39$ 206.99/208.49 $263.09 / 263.91$ $285.21 / 286.05$ 297.97/301.01 $316.99 / 318.56$ $332.09 / 332.37$ $344.37 / 345.01$ $353.26 / 353.41$ $361.61 / 363.87$ $388.73 / 390.24$ $391.57 / 396.85$ $407.85 / 408.61$ $424.44 / 425.37$

$448.89 / 450.39$

Hole $608 \mathrm{~A}$

Brunhes
Jaramillo

Olduvai

(top)
(bottom)
(top)
(bottom)
(top)
(bottom)

0.73

$3-4,120 / 3-5,94$ $3-6,114 / 4-1,98$ $4-1,98 / 4-2,98$ $7-4,98 / 7-5,98$ $7-5,98 / 7-6,98$ 9-2, 98/9-3, 98 $9.4,98 / 9-5,98$ $11-3,98 / 11-4,35$ $12-4,35 / 12-4,98$

$17.71 / 18.95$ $20.65 / 22.59$ 22.59/24.09 $55.89 / 57.39$ $57.39 / 58.89$ $72.09 / 73.59$

$75.09 / 76.59$ 92.79/93.66 $103.26 / 103.89$
Hole 609

$\begin{array}{lrr}\begin{array}{lr}\text { Brunhes } \\ \text { Jaramillo }\end{array} & \begin{array}{r}\text { (top) } \\ \text { (bottom) }\end{array} & 0.91 \\ \text { Cobb Mtn. } & \text { (top) } & - \\ & \text { (bottom) } & - \\ - & \text { (top) } & - \\ & \text { (bottom) } & - \\ \text { Olduvai } & \text { (top) } & 1.66 \\ & \text { (bottom) } & 1.88 \\ \text { Reunion } & \text { (top) } & - \\ & \text { (bottom) } & - \\ \text { Matuyama/Gauss } & & 2.47 \\ \text { Kaena } & \text { (bottom) } & 2.99 \\ \text { Gauss/Gilbert } & & 3.40 \\ \text { Cochiti } & \text { (top) } & 3.88 \\ & \text { (bottom) } & 3.97 \\ \text { Nunivak } & \text { (top) } & 4.10 \\ & \text { (bottom) } & 4.24 \\ \text { C1 } & \text { (top) } & 4.40 \\ & \text { (bottom) } & 4.47 \\ \text { Chron 5 } & \text { (top) } & 5.35 \\ & \text { (bottom) } & 5.54 \\ & \text { (top) } & 5.68\end{array}$

$5-5,98 / 5-6,98$ $7-1,98 / 7-2,98$ 7-6, 98/8-1, 98 $9-1,20 / 9-1,98$ 9-2, 18/9-2, 98 $12-1,20 / 12-1,98$ $12-1,98 / 12-2,20$ $13-4,98 / 13-5,98$ 15-1, 80/15-2, 98 $16-4,20 / 16-4,98$ $16-5,20 / 16-5,98$ 19-2, 68/19-2, 135 $24-1,98 / 24-2,138$ $26-2,100 / 26-3,100$ 28-1, 98/28-2, 98 $28-4,116 / 28-5,116$ $28-6,110 / 29-1,98$ $29-5,96 / 29-6,96$ $30-2,94 / 30-3,114$ $30-5,126 / 30-6,72$ $35-6,80 / 36-1,87$ $36-4,75 / 36-5,97$ $37-3,112 / 37-4,119$
42.79/44.29 $55.99 / 57.49$ $63.49 / 65.59$ $74.41 / 75.19$ $75.89 / 76.69$ $103.21 / 103.99$ $103.99 / 104.71$ $118.09 / 119.59$ $131.41 / 133.09$ $144.91 / 145.69$ $146.41 / 147.19$ $171.19 / 171.86$ $217.99 / 219.89$ $238.71 / 240.21$ $256.39 / 257.89$ $261.07 / 262.57$ $264.60 / 265.99$ $271.97 / 273.47$ $277.05 / 278.75$ $281.87 / 282.83$ $330.91 / 333.08$ $337.46 / 339.18$ $345.93 / 347.50$

Hole 609B

$\begin{array}{lrr}\begin{array}{lrl}\text { Brunhes } \\ \text { Jaramillo }\end{array} & \begin{array}{r}\text { (top) } \\ \text { (bottom) }\end{array} & 0.91 \\ \text { Cobb Mtn. } & \text { (top) } & - \\ & \text { (bottom) } & - \\ \text { (top) } & - \\ \text { Olduvai } & \text { (bottom) } & - \\ \text { Reunion } & \text { (top) } & 1.66 \\ \text { Matuyama/Gauss } & \text { (bottom) } \\ \text { Kaena } & \text { (top) } & 2.47 \\ & \text { (bottom) } & 2.99 \\ \text { Mammoth } & \text { (top) } & 3.08 \\ & \text { (bottom) } & 3.18\end{array}$

$\begin{array}{cc}6-1,38 / 6-1,98 & 42.39 / 42.99 \\ 7-4,60 / 7-4,110 & 56.71 / 57.19 \\ 8-2,48 / 8-2,98 & 63.19 / 63.69 \\ 9-2,98 / 9-3,80 & 73.29 / 74.61 \\ 9-3,98 / 9-4,98 & 74.79 / 76.29 \\ 12-2,98 / 12-3,98 & 102.09 / 103.59 \\ 12-3,98 / 12-4,98 & 103.59 / 105.09 \\ 13-6,98 / 14-1,98 & 117.69 / 119.79 \\ 17-1,98 / 17-1,146 & 144.49 / 146.47 \\ 19-5,98 / 19-6,98 & 169.69 / 171.19 \\ 23-6,98 / 24-1,98 & 209.59 / 211.69 \\ 24-4,98 / 24-5,106 & 216.19 / 217.77 \\ 25-5,102 / 25-6,103 & 227.33 / 228.84 \\ 26-4,110 / 26-5,111 & 235.51 / 237.02\end{array}$


Appendix (continued).

\begin{tabular}{cccc}
$\begin{array}{c}\text { Reversal } \\
\text { boundaries }\end{array}$ & $\begin{array}{c}\text { Age } \\
\text { (Ma) }\end{array}$ & $\begin{array}{c}\text { Core-Section, } \\
\text { level }(\mathrm{cm})\end{array}$ & $\begin{array}{c}\text { Sub-bottom } \\
\text { depth }(\mathrm{m})\end{array}$ \\
\hline
\end{tabular}

Site 609 (Cont.)

Hole 609B (Cont.)

$\begin{array}{lcccc}\text { Gauss/Gilbert } & & 3.40 & 27-5,108 / 27-6,108 & 246.59 / 248.09 \\ \text { C2 } & \text { (top) } & 4.57 & 32-1,129 / 32-2,106 & 288.80 / 290.07 \\ \text { Chron 5 } & \text { (top) } & 5.35 & 36-3,78 / 36-4,81 & 329.69 / 331.22 \\ & \text { (top) } & 5.68 & 38-1,76 / 38-2,33 & 345.87 / 346.94\end{array}$

Hole $609 \mathrm{C}$

\begin{tabular}{|c|c|c|c|c|}
\hline Olduvai & (bottom) & 1.88 & $1-4,98 / 2-1,98$ & $128.69 / 133.79$ \\
\hline Reunion & (top) & & $2-4,98 / 2-5,90$ & $138.29 / 139.71$ \\
\hline
\end{tabular}

Hole 610

$\begin{array}{lrrc}\text { Brunhes } & & 0.73 & 5-2,67 / 5-4,107 \\ \text { Kaena } & \text { (top) } & 2.92 & 6-2,98 / 6-3,98 \\ & \text { (bottom) } & 2.99 & 6-4,98 / 6-5,98 \\ \text { Mammoth } & \text { (top) } & 3.08 & 7-1,97 / 7-2,97 \\ & \text { (bottom) } & 3.18 & 7-4,97 / 7-5,97 \\ \text { Gauss/Gilbert } & & 3.40 & 7-7,30 / 8-1,97 \\ \text { Chron C5C } & \text { (bottom) } & 16.98 & 21-1,131 / 21-2,91 \\ \text { Chron C5D } & \text { (top) } & 17.57 & 22-4,124 / 22-5,120 \\ & \text { (bottom) } & 17.90 & 22-6,90 / 23-1,139 \\ \text { Chron C5E } & \text { (top) } & 18.56 & 23-2,57 / 24-1,61 \\ & \text { (bottom) } & 19.09 & 25-2,73 / 25-3,136 \\ \text { Chron C6 } & \text { (top) } & 19.35 & 25-3,136 / 25-4,48\end{array}$

$40.58 / 43.98$ $149.49 / 150.99$ $152.49 / 153.99$ $157.58 / 159.08$ $162.08 / 163.58$ $165.91 / 1667.19$ $657.12 / 658.22$ $671.15 / 672.61$ $673.81 / 676.40$ $677.08 / 685.22$ $697.07 / 697.94$ $697.94 / 699.19$

Hole 610A

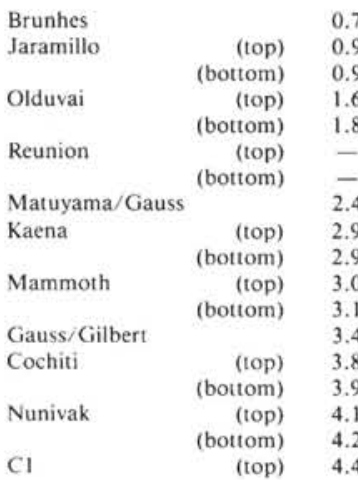

0.73
0.91
0.98
1.66
1.88
-
-
2.47
2.92
2.99
3.08
3.18
3.40
3.88
3.97
4.10
4.24
4.40

$5-3,80 / 5-4,100$

6-4, 85/6-5, 97

6-6, 97/7-1, 97

$10-5,75 / 10-6,108$

$11-2,97 / 11-3,97$

$12-1,94 / 12-2,97$

$12-2,97 / 12-3,124$

$14-2,97 / 14-3,97$

$16-5,97 / 17-1,97$

$17-1,97 / 17-2,97$

$17-3,97 / 17-4,99$

$17-6,99 / 18-1,97$

$18-4,97 / 18-5,97$

$19-3,97 / 19-4,97$

$19-5,97 / 19-6,57$

20-6, 97/21-1, 97

$21-3,97 / 21-4,97$

$21-4,97 / 21-5,97$

Hole $610 \mathrm{~B}$

$\begin{array}{lr}\begin{array}{l}\text { Brunhes } \\ \text { Jaramillo }\end{array} & \begin{array}{r}\text { (top) } \\ \text { (bottom) } \\ \text { (top) }\end{array} \\ \text { Olduvai } & \begin{array}{r}\text { (bottom) } \\ \text { (top) } \\ \text { (bottom) } \\ \text { (top) }\end{array} \\ \text { Reunion } & \text { (bottom) }\end{array}$

$$
\begin{array}{lc}
0.73 & 6-1,97 / 6-2,97 \\
0.91 & 7-1,97 / 7-2,97 \\
0.98 & 7-5,97 / 7-6,97 \\
- & 8-2,97 / 8-3,97 \\
- & 8-3,97 / 8-4,97 \\
1.66 & 11-4,97 / 11-5,97 \\
1.88 & 12-2,95 / 12-3,101 \\
- & 13-2,97 / 13-3,101 \\
- & 13-3,101 / 13-4,101 \\
2.47 & 16-3,99 / 16-4,97
\end{array}
$$

41.61/43.31

$52.76 / 54.38$

$55.88 / 57.98$

$92.56 / 94.39$

$97.88 / 99.38$

$105.95 / 107.48$ $107.48 / 109.25$ $126.68 / 128.18$ $150.38 / 153.98$ $153.98 / 155.48$ $156.98 / 158.48$ $161.50 / 163.58$ $168.08 / 169.58$ $176.18 / 177.68$ $179.18 / 180.28$ $190.28 / 192.38$ $195.38 / 196.88$ $196.88 / 198.38$
Hole $610 \mathrm{C}$

\section{Brunhes}

Reunion

$$
\begin{array}{r}
\text { (top) } \\
\text { (bottom) }
\end{array}
$$$$
0.73
$$

$44.18 / 44.68$

$53.78 / 55.28$

$59.78 / 61.28$

$64.88 / 66.38$

$66.38 / 67.88$

$96.68 / 98.18$

$103.26 / 104.86$

$112.88 / 114.42$

$114.42 / 115.92$

$141.20 / 142.68$

Hole 610D

Brunhes
$40.42 / 41.13$

$104.74 / 105.98$

$105.98 / 107.48$
Appendix (continued).

\begin{tabular}{ccccc}
\hline \multicolumn{2}{c}{$\begin{array}{c}\text { Reversal } \\
\text { boundaries }\end{array}$} & $\begin{array}{c}\text { Age } \\
\text { (Ma) }\end{array}$ & $\begin{array}{c}\text { Core-Section, } \\
\text { level (cm) }\end{array}$ & $\begin{array}{c}\text { Sub-bottom } \\
\text { depth (m) }\end{array}$ \\
\hline \multicolumn{6}{c}{ Site 610 (Cont.) } \\
Hole 610D (Cont.) & & & & \\
Jaramillo & $\begin{array}{r}\text { (top) } \\
\text { (bottom) } \\
\text { (top) }\end{array}$ & 0.91 & $4-4,110 / 4-5,80$ & $42.81 / 43.44$ \\
Cobb Mtn & 0.98 & $4-6,60 / 4-6,96$ & $45.31 / 45.67$ \\
& (bottom) & & $5-2,140 / 5-3,115$ & $49.71 / 50.96$ \\
& & & $5-4,92 / 5-5,97$ & $52.23 / 53.78$
\end{tabular}

Hole $610 \mathrm{E}$

Chron 6
Chron 7

$\begin{array}{rlc}\text { (bottom) } & 6.50 & 3-2,97 / 3-3,75 \\ \text { (top) } & 6.70 & 5-1,97 / 5-2,75 \\ \text { (bottom) } & 6.78 & 5-2,75 / 5-3,75 \\ \text { (top) } & 6.85 & 6-3,103 / 6-4,12 \\ \text { (bottom) } & 7.28 & 7-2,128 / 7-3,126\end{array}$

$281.68 / 281.96$ 299.38/300.66 $300.66 / 302.16$ $312.04 / 312.63$ $320.39 / 321.87$

Site 611

Hole 611

Brunhes
Jaramillo
Cobb Mtn.
Olduvai
Reunion

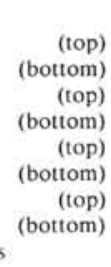

$0.73 \quad 3-6,97 / 4-1,97$ 4-6, 97/5-1, 97 $5-3,97 / 5-4,97$ $5-6,97 / 6-1,105$ 6-1, 105/6-2, 97 $7-6,97 / 8-1,97$

Matuyama/Gauss

$8-6,80 / 9-1,97$

$9-2,97 / 9-3,97$

$9-3,97 / 9-4,97$

$2.47 \quad 13-3,97 / 13-4,97$

$19.08 / 21.18$ $28.68 / 30.78$ $33.78 / 35.28$ $38.28 / 40.46$ $40.46 / 41.88$ $57.48 / 59.58$ $66.91 / 69.18$ $70.68 / 72.18$ $72.18 / 73.68$ $110.58 / 112.08$

Hole $611 \mathrm{~A}$

$\begin{array}{lr}\begin{array}{lr}\text { Brunhes } \\ \text { Jaramillo }\end{array} & \text { (top) } \\ \text { Olduvai } & \text { (bottom) } \\ \text { Matuyama/Gauss } & \end{array}$

0.73
0.91
0.98
1.88

$3-3,97 / 3-4,97$ $4-3,98 / 4-4,98$

4-6, $98 / 5-1,120$

$1.88 \quad 8-4,98 / 8-5,110$

$12-5,127 / 13-1,100$

$20.78 / 22.28$ $30.39 / 31.89$ $34.89 / 37.21$

$70.29 / 71.91$ $110.48 / 113.81$

Hole 61ID

Kaena

Mammoth

$\begin{array}{rr}\text { (top) } & 2.92 \\ \text { (bottom) } & 2.99 \\ \text { (top) } & 3.08 \\ \text { (bottom) } & 3.18 \\ & 3.40 \\ \text { (top) } & 3.8\end{array}$

$4-4,97 / 4-5,97$ $5-2,97 / 5-3,97$ $6-1,97 / 6-2,97$ $8-1,104 / 8-2,97$

Gauss/Gilbert $10-3,100 / 10-4,100$ Cochiti $14-1,140 / 14-2,97$

$153.58 / 155.08$ $160.18 / 161.68$ $168.28 / 169.78$ $177.95 / 179.38$ $200.11 / 201.61$

Hole $611 \mathrm{E}$ Brunhes
Jaramillo

(top)

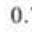

0.73

$2-5,97 / 2-6,97$ $2-6,97 / 2-7,10$

$23.08 / 24.58$ $24.58 / 25.21$

Hole $611 \mathrm{C}$

$\begin{aligned} & \text { Brunhes } \\ & \text { Olduvai } \\ & \text { Reunion }\end{aligned}$
Matuyan
Kaena
Mammo
Nunivak
C1
Chron 5
Chron 6

Chron 7
$32.61 / 34.09$ $78.01 / 80.59$ $86.59 / 88.09$ $96.01 / 97.68$ $97.68 / 99.78$ $120.54 / 121.98$ $152.28 / 153.78$ $155.28 / 157.41$ $224.56 / 225.76$ $227.56 / 234.18$ $244.46 / 250.16$ $339.44 / 340.53$

$374.12 / 375.65$

$381.41 / 382.93$ $382.93 / 384.35$ $384.35 / 385.42$ $369.01 / 371.20$ 